\author{
Cezary Kuklo \\ ORCID: http://orcid.org/0000-0002-6068-4278 \\ University of Białystok, Faculty of History and International Relations \\ email: cz.kuklo@life.pl
}

\title{
Did the Abolition of Serfdom Affect the Life Cycle of Peasants in the Western Part of the Grodno Governorate in the 19th and Early 20th Centuries?*
}

\section{Czy uwłaszczenie wpłynęło na cykl życiowy chłopów w zachodniej części guberni grodzieńskiej w XIX i początkach XX wieku?}

\begin{abstract}
The objective of the article is an attempt to find the answer to whether the agrarian reforms of the 1860 s carried out in Russia affected the individual's life cycle in peasant Catholic families in Podlasie which, after 1807, was included in the Grodno Governorate. In Polish historiography the subject of the individual and the family's life cycle in the 19th century has not yet been adequately researched; hence these studies are intended to fill this gap, at least in part. In this paper a cross-section
\end{abstract}

\begin{abstract}
Abstrakt
Celem artykułu jest próba odpowiedzi na pytanie, czy reformy agrarne lat 60 . XIX wieku przeprowadzone w Rosji wpłynęły na cykl życia jednostki w rodzinach katolickich chłopów na Podlasiu, które po 1807 roku zostało włączone w skład guberni grodzieńskiej. W polskiej historiografii temat cyklu życia jednostki i rodziny w XIX wieku jest nieopracowany, zatem niniejsze badania mają wspomnianą lukę choć w części wypełnić. W pracy posłużono się przekrojową analizą zjawisk
\end{abstract}

* This paper was created as a part of the project "Modernisation Processes in the Traditional Peripheral European Society," financed by the National Science Center based on decision no. DEC-2014/15/B/HS3/02202. 
analysis of demographic phenomena was employed, which is based on three lists of the inhabitants of the large Podlasie parish of Trzcianne, drawn up in the years 1843-1910. The research value of the lists was evaluated with the help of three indexes: Whipple's index, the total modified Whipple's index $\left(\mathrm{W}_{t o t}\right)$ and ABCC. The application of the cross-section method aimed at illustrating the dependence between the age and the status of the individual (children, household servants, householders, independent female heads of households, relatives and lodgers) in the household. The article devotes more attention to the pace of children's leaving family homes, as well as the status of old people, i.e., 65 years old and above, always including their sex.

\section{Keywords}

life cycle, peasants, status in the household, lists of parishioners, Grodno Governorate, Podlasie demograficznych, opartą na trzech spisach mieszkańców dużej parafii podlaskiej Trzcianne, sporządzonych w latach 18431910. Wartość badawczą spisów oceniono, stosując trzy indeksy: Whipple'a, zmodyfikowany Whiplle'a $\left(\mathrm{W}_{t o t}\right)$ oraz ABCC. Zastosowanie metody przekrojowej miało na celu zobrazowanie zależności między wiekiem a pozycją jednostki (dzieci, służba domowa, gospodarze, samodzielne kierowniczki gospodarstw, krewni i kątnicy) w gospodarstwie domowym. W artykule w większym stopniu zwrócono uwagę na tempo opuszczania przez dzieci chłopskie domu rodzinnego oraz na pozycję ludzi starych, to jest w wieku 65 i więcej lat, zawsze $\mathrm{z}$ uwzględnieniem ich płci.

\section{Słowa kluczowe}

cykl życia, chłopi, pozycja w gospodarstwie domowym, spisy wiernych, Gubernia Grodzieńska, Podlasie

\section{Introduction}

Even though the emancipation of peasants in Polish-speaking lands in the 19th century took different courses, more favorable for land owners in Prussia and Russia, while more favorable for peasants in the Habsburg monarchy and in the Congress Kingdom of Poland, ${ }^{1}$ as Stefan Kieniewicz, the outstanding Polish historian noted, "The emancipation reform opened the way for a free game of capitalist forces." ${ }^{2}$ It is also worth observing that even in the Kingdom of Poland

${ }^{1}$ Elżbieta Kaczyńska, Kazimierz Piesowicz, Wykłady z powszechnej historii gospodarczej (od schytku średniowiecza do I wojny światowej) (Warszawa: Państwowe Wydawnictwo Naukowe, 1977), 324-330; Andrejs Plakans, "Agrarian Reform and the Family in Eastern Europe," in: Family Life in the Long Nineteenth Century 1789-1913, eds. David I. Kertzer, Marzio Barbagli (New Haven-London: Yale University Press, 2002), 85-89.

${ }^{2}$ Stefan Kieniewicz, Historia Polski 1795-1918 (Warszawa: Państwowe Wydawnictwo Naukowe, 1970), 285. 
and Russia, the agriculture of which in the first 25 years after the emancipation remained in its traditional forms, the peasants found themselves in a new legal, economic and social situation. New factors, previously unknown, began to affect the peasant economy in the second half of the 19th century. ${ }^{3}$ Demographic pressure was the most important. Malthusian mechanisms of population control (famines, epidemics) were gradually reduced, which resulted in an increase in the pace of natural growth and thereby in the progressing overpopulation of the countryside. The market effect was of no less significance, for the tsar's ukase issued in 1863 prescribed an immediate and obligatory buyout of the land by the peasants, on the basis thereof all obligated to do so passed to the category of "peasant-owners". In 1867, the emancipation reform in the Western governorates of the Tsardom also covered peasants in state estates. They received the land they had previously cultivated. Simultaneously, land was to be granted to the landless, soldiers on leave and veterans, bobyls or gardeners in order to complement the areas of farms. ${ }^{4}$ The top-down and compulsory emancipation of peasants resulted in their becoming involved in the market, since it became necessary for them to seek various sources of income (from odd jobs to permanent), which would allow them to buy out the land they cultivated, not mentioning the taxes paid to the state or to the Church. Thus, there was fiscal pressure from the state. On the other hand, the subdivision of smaller folwarks (manor farms) resulting from the agrarian crisis of the 1880 s enabled more ambitious individuals to buy more folwark land or to take over the farms (or their parts) of their neighbors who were struggling in the new economic situation. The ties of the peasant's farm and the market were strengthened with the course of time through purchasing better tools produced by industry (later on also artificial fertilizers), which enabled them to intensify cultivation and breeding.

In this situation of limited land resources, the fast growth of the farming population, despite its migration to cities, also forced different inheritance customs: estates were increasingly divided among the children of both sexes. This

\footnotetext{
${ }^{3}$ The whole sphere of issues regarding peasants' perception of the civilizational changes in the rural environment of their inclusion into national culture exceed our considerations. For information, see Maria Krisań, Chłopi wobec zmian cywilizacyjnych w Królestwie Polskim w drugiej połowie XIX - na początku XX wieku (Warszawa: Wydawnictwo: NERITON, 2008); eadem, "Świadomość narodowa polskich chłopów w XIX w. widziana przez historiografię polską po drugiej wojnie światowej," Historyka 34 (2004): 123-141; Nikodem Bończa-Tomaszewski, "Polskojęzyczni chłopi? Podstawowe problemy nowoczesnej historii chłopów polskich," Kwartalnik Historyczny 112 (2005), 2: 91-111 and Włodzimierz Mędrzecki, Szymon Rudnicki, Janusz Żarnowski, Spoleczeństwo polskie w XX wieku (Warszawa: Instytut Historii PAN, 2003), 120-121.

${ }^{4}$ Jerzy Szumski, "Uwłaszczenie chłopów w obwodzie białostockim oraz w północno-wschodniej części Królestwa Polskiego," in: Wieś i rolnictwo ziem pólnocno-wschodniej Polski w II połowie XIX i poczatkach XX w., ed. Adam Dobroński (Białystok: Dział Wydawnictw Filii Uniwersytetu Warszawskiego w Białymstoku, 1984), 43.
} 
was a fundamental change in comparison with the declining phase of the feudal system, when the dowry of a peasant's daughter given away in marriage almost never included real estate, and children were not bequeathed an inheritance via a written will but through an oral promise in front of witnesses. It is worth adding that in 19th-century Russia, in reference to the rural population, even after the abolition of serfdom in 1861 there were no written legal regulations on inheriting property. Therefore, peasants referred to local customs, which said that married sons remaining on their father's farm after his death divided the inherited property into equal parts. In turn, with the moment of marriage and moving to another farm, daughters lost the right to inherit from their parents. ${ }^{5}$

Even though Jacek Kochanowicz defines the post-traditional peasant farm as still semi-natural, geared towards only supplying enough food to survive, "Money plays $[. .$.$] an incomparably greater role than in the traditional farm." In this$ context, it is difficult not to pose two important research questions. Did involving the peasant farm into the market as a result of emancipation in any way affect the size and structure of the household, determining the workforce, and did it result in transformations in the demographic life cycle of peasants in the Podlasie village in the late 19th century and early 20th century? The answer to the first of the research questions, due to its size, will be set aside for a separate paper, whereas below we will try to answer the second question, which concerns the life cycle of the individual in the Podlasie village, which administratively belonged to the Grodno Governorate of the Russian Empire.

The subject of this work refers in a way to the research of Polish sociologists specializing in rural issues, which have had a long tradition in Poland going back to before World War II. As early as then, Florian Znaniecki and Józef Chałasiński noted the enormous importance of the family as the only organized social group in the rural environment, which embraced particular peasants ${ }^{7}$. It is the peasant family and its household functioning at the end of the period of serfdom, as well as after the abolition of serfdom and affranchisement in Polish-speaking lands incorporated into Russia, which is the main subject of our analyses. Sharing the

${ }^{5}$ S. Muzykant, "Włościańskie prawo spadkowe w województwie poleskim i 5 wschodnich powiatach wojew. białostockiego," in: Adam Bobkowski, S. Muzykant, Kazimierz Petrusiewicz, Witold Sienkiewicz, Zwyczaje spadkowe włościan w Polsce, cz. IV: Zwyczaje spadkowe włościan $w$ czterech województwach kresowych (Warszawa: Nakładem Państw. Instytutu Naukowego Gosp. Wiejsk. w Puławach, 1929), 213-229.

${ }^{6}$ Jacek Kochanowicz, Spór o teorie gospodarki chtopskiej. Gospodarstwo chtopskie w teorii ekonomii $i$ w historii gospodarczej (Warszawa: Wydawnictwa Uniwersytetu Warszawskiego, 1992), 196.

${ }^{7}$ William I. Thomas, Florian Znaniecki, The Polish Peasant in Europe and America, vol. 1 (New York: Alfred A. Knopf, 1927), 140; Józef Chałasiński, Młode pokolenie chłopów. Procesy i zagadnienia ksztaltowania się warstwy chłopskiej w Polsce (Warszawa: Państwowy Instytut Kultury Wsi, 1938), 133-135. 
view of many rural sociologists, primarily Danuta Markowska, on the family as a fundamental component of the rural organization of social life and not the human individual, at least by the beginning of the 20th century, ${ }^{8}$ we want to scrutinize more closely the individual life of a peasant considered through the prism of his place in the family community. Sociologists underscore the impact of affranchisement in eliminating the basis of the previous isolation of peasant communities, in breaking local barriers and introducing peasant households into the orbit of increasingly stronger connections with market and money circulation. ${ }^{9}$ In the new reality, where a great number of families were forced to strive for earnings, where the traditional model of the division of household chores ascribed to gender, age and place in the family structure, was of increasingly lower relevance,$^{10}$ it seems reasonable to also try to observe a typical individual life cycle within the framework of the family community.

\section{Aims of the article and research area}

In the face of the modernization of the peasant economy located on the peripheries, we pose the hypothesis that the civilizational challenges of the center, including the need for money, changed peasants' behavior as regards attitudes towards the family, visible in the founding and duration of their households. We shall test the hypothesis through applying the cross-section method for the examined cohort of Podlasie peasants, i.e., the age declared by particular individuals at a determined moment in time, which we shall be synchronizing with individual life stages of the peasants in the family. This will allow us to follow dynamically the life cycles or life courses of the inhabitants of Podlasie villages. This approach, resulting from the sociological theory of the family development cycle, ${ }^{11}$ is broadly applicable in the world demography of the past ${ }^{12}$ and considerably

${ }^{8}$ Danuta Markowska, Rodzina w społeczności wiejskiej-ciagłość i zmiana (Warszawa: Ludowa Spółdzielnia Wydawnicza, 1976), 44; Ludwik Stomma, Antropologia kultury wsi polskiej XIX wieku oraz wybrane eseje (Łódź: Wydawnictwo Piotr Dopierało, 2002), 253-254.

${ }^{9}$ Chałasiński, Młode pokolenie, 138-139; Danuta Markowska, Rodzina wiejska na Podlasiu 1864-1964 (Wrocław: Zakład Narodowy imienia Ossolińskich, 1970), 85, 196; Bohdan Baranowski, Życie codzienne wsi między Wartą a Pilicą (Warszawa: Państwowy Instytut Wydawniczy, 1969), 18; see also Stanisław Borowski, Rozwarstwienie wsi Wielkopolskiej w latach 1807-1914. Studium statystyczne nad społecznymi i ekonomicznymi nastepstwami wtaczenia wsi w orbite rynku (Poznań: Rada Naukowo-Ekonomiczna przy Prezydium WRN w Poznaniu, 1962), 21, 82.

${ }^{10}$ Markowska, Rodzina w spoteczności wiejskiej, 131.

${ }^{11}$ Ewa Frątczak, Modelowanie cyklu życia jednostki i rodziny. Teoria i praktyka (Warszawa: Oficyna Wydawnicza SGH, 1999), 39-87.

${ }^{12}$ See collected works in the volumes The Family Life Cycle in European Societies, ed. Jean Cuisenier, (Hague: Mouton de Gruyter, 1977); Transitions. The Family and the Life Course in Historical Perspective, ed. Tamara K. Hareven, (New York-San Sebastian-London: Academic 
rarer in Polish historiography. In previous, infrequent, analyses of family forms in Polish-speaking lands from the end of the 18th century, peasants' life cycles have been observed only by Michał Kopczyński ${ }^{13}$ and Mikołaj Szołtysek, ${ }^{14}$ and in reference to a work on burghers by Cezary Kuklo. ${ }^{15}$ Polish literature still lacks attempts at demonstrating the typical life cycle of the individual in the village in the post-emancipation period, in the second half of the 19th century and the early 20th century.

The study covered the years 1843-1910. The start point and the basis for further comparisons is the year 1843, which will show the characteristic qualities of the Podlasie peasant's life cycle in the Grodno Governorate at the end of the late feudal period, which means before the agrarian reforms in Russia of 1861-1867. ${ }^{16}$ The upper cut-off point is 1910, which enables us to learn about the issue in the community of peasants living and working for nearly half a century in a legal and socio-economic environment which was different from that of their grandfathers and fathers. We are positive that this chronological perspective of nearly seven decades is sufficient for a detailed reconstruction of family development cycles observed in reference to individuals. However, striving to better track changes in time, we decided to observe, in a somewhat controlled manner, still another time interval, namely the year 1882 .

In-depth studies covered the cohorts of peasants residing in the Roman-Catholic parish of Trzcianne, one of the most populated in Podlasie. ${ }^{17}$ The parish, with origins dating from the end of the 15th century, encompassed vast lands situated

Press, 1978); Land, Kinship and Life-Cycle, ed. Richard M. Smith (Cambridge: Cambridge University Press, 1984) and Richard Wall, "Leaving Home and the Process of Household Formation in Pre-Industrial England," Continuity and Change 2 (1987), 1: 77-101. For information on the achievements of the research perspectives of the developmental approach to the family structure, see Mikołaj Szołtysek, "Demografia historyczna i co dalej? Nowe perspektywy w badaniach nad historią rodziny XVI-XIX wieku," Roczniki Dziejów Społecznych i Gospodarczych 62 (2003): 132-137.

${ }^{13}$ Michał Kopczyński, "Cykl życia jednostki na wsi polskiej u schyłku XVIII wieku," Studia Demograficzne 127 (1997): 97-115; idem, Studia nad rodzina chtopska w Koronie w XVII-XVIII wieku (Warszawa: Wydawnictwo Krupski i S-ka, 1998), 115-167; idem, "Life Cycle of Individuals in the Country of Poland at the End of the 18th Century," Polish Population Review 10 (1997): 228-247; idem, "Life Cycle in the Polish Countryside in the Late 18th Century," Acta Poloniae Historica 97 (2008): 75-94.

${ }^{14}$ Mikołaj Szołtysek, Rethinking East-Central Europe: Family Systems and Co-Residence in the Polish-Lithuanian Commonwealth, vol. 1 (Bern: Peter Lang, 2015).

${ }^{15}$ Cezary Kuklo, "Społeczno-demograficzny cykl życia człowieka w mieście staropolskim u schyłku XVIII wieku," Roczniki Dziejów Spolecznych i Gospodarczych 62 (2002): 85-105.

${ }^{16}$ Similarly, Matti Polla, "Family Systems in Central Russia in the 1830 and 1890s," The History of the Family 11 (2006), 1: 28, who considers the functioning of the household system in the periods $1808-1834$ and $1877-1897$ and emphasizes the major change in peasants' business activity after their emancipation.

${ }^{17}$ The small nobility group remains outside the scope of our research. 
in the arch of two rivers, the Biebrza and the Narew. ${ }^{18}$ In the mid-19th century it included 55 villages and 10 manors of more affluent nobility..$^{19}$ The majority of the 55 parish settlements in the 1840 s consisted of $32(58 \%)$ small villages of a maximum 10 houses, $20 \%$ of all the villages being settlements of fewer than 4 houses. ${ }^{20}$ The latter were located far from the parish center, on the outskirts of woods and the Biebrza marshes. There were also, however, densely populated villages, since every fourth village had over 21 residential houses. Before the emancipation, peasants in the parish under scrutiny were legally situated in the group of private and state-owned peasants.

Within the church administration structure, the Parish of Trzcianne belonged to Białystok Deanery in the Diocese of Vilnius, and in the state administrative structure it was part of Białystok District in Białystok Oblast, which in 1842, by decree of Tsar Nicholas I, was included into the Grodno Governorate, ${ }^{21}$ one of the 9 western governorates of the empire. ${ }^{22}$

Podlasie, the borderland between the Polish Crown and Lithuania, both in the Old Polish era, as well as in the later years of the Romanov empire, was a typically agricultural land, poor in natural resources. Even after emancipation, the standard of cultivation on peasant farms was still primitive, for the traditional threefield system dominated, although over the course of time it was replaced by the fallowless three-field system. In the Białystok district, in the territory of which the village community in this study lived, approximately two thirds of all the farmland belonged to peasants. In the nearest neighborhood, not far from the parish center (c. $30 \mathrm{~km})$ were three small towns: Knyszyn, Tykocin and Goniądz, which at the end of the 19th century had c. 3,400-3,700 inhabitants each. A little farther, c. $50 \mathrm{~km}$ away, was the dynamically developing Białystok with its 62,000 residents in 1897. At that time, it constituted a considerable industrial center, since

${ }^{18}$ Tomasz Jaszczołt, "Fundacje kościelne na Podlasiu do końca XV wieku,” In: Kościoły a państwo na pograniczu polsko-litewsko-białoruskim. Źródła i stan badań, eds. Marek Kietliński, Krzysztof Sychowicz, Wojciech Śleszyński (Białystok: Wydawnictwo Prymat Mariusz Śliwowski, 2005), 47; Wiesława Wernerowa, "Opisy parafii dekanatu augustowskiego z roku 1784," Studia Podlaskie 4 (1993): 222-224.

${ }^{19}$ Executorium Decretum De Limitibus Dioecesis Vilnensis Latum ab Illustrissimo et Reverendissimo Domino Matropolitano Ignatio Hołowiński (Vilnae, 1854), 80-81.

${ }^{20}$ Cezary Kuklo, "Ludność parafii Trzcianne w świetle spisu wiernych z 1843 roku," Przeszłość Demograficzna Polski 38 (2016), 3: 83-84, 95.

${ }^{21}$ Adam Dobroński, ed., Historia województwa podlaskiego (Bialystok: Instytut Wydawniczy Kreator, 2010), 141.

${ }^{22}$ Russia created 9 governorates on the territories taken from Poland in the three partitions, which happened towards the end of the 18 th century, over a surface area of $469,400 \mathrm{sq}$. km (including the Białystok Oblast taken from Prussia in 1807): 3 Lithuanian (Grodno, Vilnius and Kaunas), 3 Belorussian (Minsk, Mogilev and Vitebsk), and 3 Ukrainian (Volhynia, Podolia and Kiev). According to the first estimation for this area made in 1846, the population was 9.8 million, and in 1870,12 million. 
$48 \%$ of its active population worked in industry and $14 \%$ in commerce. From 1873 onwards, the peasants of the Trzcianne parish began using, alongside the old ways and roads, the new railroad between Brest-Litovsk and Grajewo. The Brest-Grajewo railroad connected the direct rail traffic from Odessa via Kiev, Brest-Litovsk, Bielsk and Białystok to the frontier town of Grajewo and farther to Lyck and Konigsberg, Prussia. One of the stations on the Brest-Grajewo Railroad was in Mońki, a place about $11 \mathrm{~km}$ from the parish center.

\section{Sources. Data value}

Adopting the family development cycle theory in this study required the analysis to be based on censuses. However, there are no such materials for the determined chronological period in the Grodno Governorate, and the only common census in the Romanov empire of 1897 did not include the information we need; detailed analyses were based on 3 parish population name lists compiled by the Catholic clergymen of the parish under scrutiny. ${ }^{23}$ All three lists of parishioners for the years 1843, 1882 and 1910 were drawn up by the parish parsons who, when recording the parish residents, also used the work of their subordinates, vicars. At the moment the list was prepared, each of them had over a dozen years' work experience in the parish, and we may assume that they knew the parish very well. The name lists used here were prepared in subsequent villages and their homes. In the course of the operation to register the faithful, clergymen reached even small settlements, often of two or three cottages, located on the peripheries of the parish. It is important to underscore that the basic record unit in the registers, regardless of the time of their preparation, was always a single household. The first person named in the household was treated, both by those who recorded it, and hence also by us in these studies, as head of the household. Besides the personal data of particular residents with their age and marital status, they identified their position in the household. When enumerating the composition of the household, a particular hierarchy was preserved: the owners (husband, wife), their children, grandparents, servants, and lodgers. Then, in a similar hierarchy, the members of lodger families were noted. The children were classed by age order, first sons, and then daughters. The sources also identify the owners' parents and parents-in-law.

The form used to prepare the lists was modeled directly on libri status animarum, introduced into the Catholic Church in the first half of the 17th century, although it was not until the second half of the 18th century that they were commonly applied in parishes in the lands of the Polish-Lithuanian Commonwealth.

${ }^{23}$ Archdiocese Archives in Białystok, Archives of the Roman Catholic parish in Trzcianne, List of parishioners from 1843; List of parishioners from 1882; List of parishioners from 1910. 
Like many other sources, the parish name lists were not drawn up for the purposes of academic studies, hence the need for an evaluation of their research value. In the case of the pre-statistic material, an important issue remains establishing the size of the age concentration resulting from determining it roughly, commonly occurring, although at different intensity, among the population of low intellectual abilities, who did not know their precise age (see Table 1). When assessing the material, it is also important to determine the regularity in the share in the population of the youngest cohort of $0-14$ years of age, more influenced by biological factors (the commonly established domination of boys among newborns and the higher mortality of $\mathrm{men}^{24}$ ) than social, such as their share in the migration processes, as well as the share of the population of the old, 60 years of age and older. In the older age groups, besides the impact of the surroundings themselves, it was the migration movement that would shape the relationships between the two sexes. In this matter it is helpful to use the masculinity ratio, i.e., the proportion of men to 100 women (see Table 2).

Table 1. Values of Whipple's indexes, total modified Whipple's index $\left(\mathrm{W}_{t o t}\right)$ and $\mathrm{ABCC}$ for peasants by sex in Trzcianne parish, 1843-1910

\begin{tabular}{lcccc}
\hline & \multicolumn{3}{c}{ Indexes } & Number \\
\cline { 2 - 4 } & Whipple's & $\begin{array}{c}\text { Whipple's } \\
\left(\mathrm{W}_{\text {tot }}\right)\end{array}$ & ABCC & \\
\hline Male & 1843 & 41.5 & 590 \\
Female & 334 & 8.43 & 39.4 & 651 \\
\hline Total & 343 & 8.57 & 40.4 & 1,241 \\
\hline & 338 & 8.45 & & 850 \\
\hline Male & 1882 & 85.9 & 917 \\
Female & 156 & 5.50 & 83.8 & 1,767 \\
\hline Total & 165 & 5.83 & 105 & 1,083 \\
\hline & 161 & 5.66 & 100 & 1,205 \\
\hline Male & 81 & 1910 & 101 & 2,288 \\
Female & 107 & 2.87 & 2.89 & \\
\hline Total & 95 & 2.83 & & \\
\hline
\end{tabular}

Source: Cezary Kuklo's data bank - List of Trzcianne parishioners from 1843; List of Trzcianne parishioners from 1882; List of Trzcianne parishioners from 1910.

${ }^{24}$ Jerzy Z. Holzer, Demografia (Warszawa: Polskie Wydawnictwo Ekonomiczne, 1999), 141; see also Alfred Perrenoud, "Le recul de la mortalité 'ordinaire'," in: Histoire des populations de l'Europe, vol. 1: La révolution démographique 1750-1914, eds. Jean-Pierre Bardet, Jacques Dupâquier (Paris: Fayard, 1998), 57-62; Massimo Livi Bacci, La population dans l'histoire de l'Europe (Paris: Éditions du SEUIL, 1999), 229-234. 
Table 2. Peasants' age structure with the masculinity ratio in Trzcianne parish, 1843-1910

\begin{tabular}{lccrcrc}
\hline \multirow{2}{*}{ Age } & \multicolumn{2}{c}{1843} & \multicolumn{2}{c}{1882} & \multicolumn{2}{c}{1910} \\
\cline { 2 - 7 } & $\%$ & $\mathrm{M} / 100 \mathrm{~F}$ & $\%$ & $\mathrm{M} / 100 \mathrm{~F}$ & $\%$ & $\mathrm{M} / 100 \mathrm{~F}$ \\
\hline $0-14$ & 36.4 & 95.2 & 37.3 & 101.0 & 37.6 & 95.4 \\
$15-59$ & 58.6 & 86.3 & 56.1 & 96.8 & 55.5 & 89.8 \\
$60+$ & 5.0 & 106.8 & 6.6 & 114.6 & 6.9 & 119.6 \\
\hline Total & 100.0 & 90.4 & 100.0 & 99.4 & 100.0 & 93.7 \\
\hline Number & 3,037 & $\times$ & 4,290 & $\times$ & 6,015 & $\times$ \\
\hline
\end{tabular}

Source: Cezary Kuklo's data bank - List of Trzcianne parishioners from 1843; List of Trzcianne parishioners from 1882; List of Trzcianne parishioners from 1910.

Among the most often used statistical instruments in examining age concentration are three indexes: Whipple's index, the modified Whipple's index $\left(\mathrm{W}_{t o t}\right)$ and the ABCC index. The first of these, somewhat classic now, since it was devised over half a century ago, measures concentrations around an age rounded to 0 or 5 and concerns cohorts from 23 to 62 years of age. A list is said to be high precision when the index values are below 105, whereas values above 175 indicate a very high age concentration and prove thereby low precision; such data are frequently described as "very primitive". ${ }^{25}$ Whipple's index, now already a classic, like many other statistical measures is far from being perfect, because younger ( $0-22$ years) and older groups (63+ years) are not included. It also fails to detect possible concentrations on other figures, such as 2 or $6 .{ }^{26}$ In recent years new interesting methodological proposals have emerged which, according to the authors, aim at a better approach to the scale of distortions of declared age. One of these was put forward by the American demographer, Thomas Spoorenberg, in Population (2007), calling the proposed measure the total modified Whipple's index Whipple's modified index $\left(\mathrm{W}_{t o t}\right)$. It detects the power of cluster tendencies around each of the ten digits and may serve as a more accurate synthetic measurement of the quality of age declaration for the whole population, from the youngest to the oldest. ${ }^{27}$ However, its interpretation is not very simple. Basically, the result may oscillate in a scale of $0-16$. The lower the scale of distortions resulting from the cluster of declared age, the closer to 0 the result of the $\left(\mathrm{W}_{t o t}\right)$ index.

\footnotetext{
${ }^{25}$ Mieczysław Kędelski, Jan Paradysz, Demografia (Poznań: Wydawnictwo Akademii Ekonomicznej w Poznaniu, 2006), 155-160.

${ }^{26}$ Certain researchers of the preindustrial population, e.g., Michał Kopczyński, illustrating the scale of distortions caused by the age concentration for the peasants of Kuyavia at the end of the 18th century, employ Meyers' index. See Kopczyński, Studia, 72-74.

${ }^{27}$ Tomas Spoorenberg, "La qualité des declarations par âge extension et application de l'indice de Whipple modifié," Population 62 (2007), 4: 847-859.
} 
Two years later, yet another form of Whipple's transformed index was proposed by three scholars, Brian A'Hearn, Jörg Baten and Dorothee Crayen, the values of which fit the range of 0 to 100 and basically give information on the percentage of people giving their age, without rounding. ${ }^{28}$ Their interesting proposal assumes that there is a strong correlation between the degree of the registered person's ignorance of their own age and their literacy and numeracy, indicating their limited contact with numbers.

Table 1 gives the Whipple's index, total modified Whipple's $\left(\mathrm{W}_{t o t}\right)$ and $\mathrm{ABCC}$ values for the examined cohort of Trzcianne peasants, including their sex, in the years 1843-1910. The high Whipple's index values for the population of peasants of 1843 described here, 338, significantly exceed the upper limit of the 5-grade scale and prove their poor knowledge of their own age at the end of serfdom, although with a slight difference in favor of men. ${ }^{29}$ The results of the modified Whipple's index $\left(\mathrm{W}_{t o t}\right)$ confirm the observations made earlier, and the differences between the sexes turn out to be insignificant, which indicates a similar, very poor level of numeracy in the Trzcianne peasants. The visible convergence of both indexes, Whipple's and modified Whipple's $\left(\mathrm{W}_{t o t}\right)$, is a consequence of the fact that peasants rounded their age primarily to years ending in 0 and 5 . Twenty years before emancipation, nearly $60 \%$ of adult peasants in the cohort under scrutiny had a very poor knowledge of their actual age and therefore provided it rounded for the list. ${ }^{30}$

Almost 40 years later, the peasants knew their age considerably better than their parents' generation, which is indicated by lower Whipple's index values

${ }^{28}$ Brian A'Hearn, Jörg Baten, Dorothee Crayen, "Quantifying Quantitative Literacy. Age Heaping and the History of Human Capital," Journal of Economic History 69 (2009), 3: 783-808. Its usefulness in Polish studies was first noticed by Radosław Poniat: "Starość ludzi luźnych. Aspekty demograficzne i ekonomiczne," in: Ludzie starzy i starość na ziemiach polskich od XVIII do XXI wieku (na tle porównawczym) vol. 1: Metodologia, demografia, instytucje opieki, eds. Agnieszka Janiak-Jasińska, Katarzyna Sierakowska, Andrzej Szwarc (Warszawa: Wydawnictwo DiG, 2016), 137.

${ }^{29}$ For example, not so distant in time, carried out just 20 years later, the census in Wielkopolska (Greater Poland, i.e., Poznan Province) of 1864 was characterized by a more accurate Whipple's index, at the level of 115.4; see Kędelski and Paradysz, Demografia, 159. Ewa Kaźmierczyk, "Spisy Komisji Porządkowej Cywilno-Wojskowej Województwa Krakowskiego jako źródło do badań demograficznych - przykład powiatu proszowickiego," Przeszłość Demograficzna Polski 38 (2016), 2: 86-89, points to a considerable differentiation in the Whipple's index values in the parochial list of population drawn up in the years 1791-1792, independently of the size of the parish.

${ }^{30}$ There are opinions in the most recent literature which recognize the age concentration intensity as one of the indicators of social development of an old population; see Dorothee Crayen and Jörg Baten, "New Evidence and New Methods to Measure Human Capital Inequality before and During the Industrial Revolution. France and the US in the Seventeenth to Nineteenth Centuries," Economic History Review 63 (2010), 2: 452-478. In the light of the ABCC index values calculated for the Trzcianne parish, we should consider its inhabitants as largely illiterate and devoid of wider contact with numbers, which does not seem entirely plausible. 
of 161. Also, the clear fall in $\mathrm{W}_{\text {tot }}$ Whipple's index values confirms this: from 8.45 to 5.66 . As late as the early $1880 \mathrm{~s}$, over $16 \%$ of women and over $14 \%$ of men rounded their ages up or down.

In comparison with the two earlier statistical examinations of Trzcianne's population, the list of the faithful compiled in 1910 stood out with its precision in the recorded age of the residents, since the Whipple's index value for the whole population was 95 . In the five-grade scale its level indicates that the rate of error in age precision remains above $5 \%$. It is also important to observe that it was still less precisely registered for women (107) than men (81). A clear improvement in the precision of registering the peasants' age is indicated by the falling values of Whipple's indexes $\left(\mathrm{W}_{t o t}\right)$; by half in comparison with the previous cross-section, from 5.66 to 2.83. The exemplary values of ABCC indexes at level 101 indicate the progress which had been made over nearly 70 years in the age awareness between the generations of grandparents and their grandchildren. The latter were generally well aware of their age, in contrast to their fathers, not to mention their grandfathers. This phenomenon may be recognized as one of the first signs of the social modernization which was taking place at the end of the 19th and early 20th centuries. ${ }^{31}$

The data in Table 2 referring to the percentage of children and young people aged $0-14$ in the individual parish lists, rising from 36.4 in 1843 to 37.6 in 1910, are fairly accurate, for with the high birth rate of that time, its value should oscillate at the level of c. $40 \%$ of the whole population. The slightly lowered percentage of children and adolescents was a result of the incomplete registration of the youngest and slightly older boys, especially in 1843 and 1910, which is indicated by an unnatural domination of girls over boys in the age group $0-14$. The official population registry, while not free from defects and faults, but of better quality than church statistics, confirms, however, that in the 19th century there was a slightly higher number of boys than girls in the under-15 age group. ${ }^{32}$ This was by no means specific to the inhabitants of Polish-speaking lands; a similar dominance of boys in the analogous age group also characterized, for example, the population of France during the First and the Second Empires. ${ }^{33}$

${ }^{31}$ It is important to remember, however, that although the Whipple's index $\left(\mathrm{W}_{t o t}\right)$ values for 1910 were far lower than the values of the same index for the census in Morocco in 1971 and in India in 1971-2001, they are also far from its values for the census in Switzerland in 1860 (0.40 for men and 0.48 for women), not to mention the census of 1900 ( 0.13 and 0.20 respectively), see Spoorenberg, "La qualité," 879.

${ }^{32}$ Irena Gieysztorowa, Wstęp do demografii staropolskiej (Warszawa: Państwowe Wydawnictwo Naukowe, 1976), 103 - data for the Duchy of Warsaw in 1810 and the population of Polishspeaking lands around 1900; Kędelski, Paradysz, Demografia, 156-157.

${ }^{33}$ Louis Henry and Yves Blayo, "La population de la France de 1740 à 1860," Population 30 (1975), 1: 92-93. See Antoinette Fauve-Chamoux, Sölvi Sogner, eds., Socio-Economic 
In the same period, at the opposite end of the scale, the share of the population of 60 and over grew systematically, from 5\% in 1843 to $6.9 \%$ in 1910 . This indicator does not seem high. However, the dominance of men in this group, increasingly visible in subsequent lists (from c. 107 to 120 men to 100 women), raises the question whether the authors of the parish lists listed all the old women. The largest share of children and adolescents (37.6\%) in the list of 1910 on the one hand, and on the other, the elderly population of over 60 year-olds $(6.9 \%)$, even counting for errors in registration, may provide evidence that, at the turn of the 20th century, the Trzcianne peasants were going through the second phase of demographic transition (a decrease in mortality while the birth rate remained at the traditional, very high level, resulting also in a lengthening of the average life expectancy to 45$){ }^{34}$

\section{The individual's life cycle 1843-1910}

\section{Before emancipation}

During the decline of serfdom, the most numerous groups of residents in the Podlasie villages located in the western part of the Grodno Governorate were children, who constituted $42.2 \%$ of the whole population (see Table 3). It is worth adding that the date refers to children and grandchildren who had not yet started their own families and were still living in their family home, since married children were treated as relatives. The visible reduction in the percentage of children in the 10-14 age group, both boys and girls, in very similar proportions (73.5$75.3 \%$ ), demonstrates that for around a quarter of them, the period of childhood was gradually coming to an end. In every subsequent age group, the share of single children is increasingly lower. By the age of 35 they had all started their own families, which may prove the enormous importance of the institution of marriage and the family issuing from it among serfs. ${ }^{35}$ In those days, the phenomenon of permanent celibacy among Trzcianne peasants was almost entirely absent (this concerned 1 man and 2 women over 50$)^{36}$.

Along with the decrease in the proportion of children, the growth in the percentage of home servants is noticeable. In the villages in the western part of the

Consequences of Sex-Ratios in Historical perspective, 1500-1900 (Milano: Università Bocconi, 1994).

${ }^{34}$ Holzer, Demografia, 19.

${ }^{35}$ Markowska, Rodzina wiejska, 129.

${ }^{36}$ Old bachelors and old manhood were rare in the villages of serfdom - see Baranowski, Życie, 125; Andrzej Woźniak, Kultura mazowieckiej wsi pańszczyźnianej XVIII i początku XIX wieku (Wrocław: Zakład Narodowy im. Ossolińskich, 1987), 87. 
Grodno Governorate, a job as a servant was not a rare phenomenon and engaged $11.8 \%$ of men and $8.8 \%$ of women. This small difference in number resulted from

Table 3. Peasants by their status in the household in Trzcianne parish, 1843 (\%)

\begin{tabular}{|c|c|c|c|c|c|c|c|c|}
\hline \multirow[t]{3}{*}{ Age } & \multicolumn{6}{|c|}{ Status in the household } & \multirow[t]{2}{*}{ Total } & \multirow[t]{2}{*}{ Number } \\
\hline & \multicolumn{6}{|c|}{ Male } & & \\
\hline & $\begin{array}{l}\text { chil- } \\
\text { dren }\end{array}$ & servants & \multicolumn{2}{|c|}{ heads of household } & relatives & lodgers & & \\
\hline $0-4$ & 100.0 & - & \multicolumn{2}{|r|}{-} & - & - & 100 & 194 \\
\hline $5-9$ & 95.8 & 0.6 & \multicolumn{2}{|r|}{-} & 3.0 & 0.6 & 100 & 167 \\
\hline $10-14$ & 75.3 & 12.6 & \multicolumn{2}{|r|}{-} & 10.3 & 1.7 & 100 & 174 \\
\hline $15-19$ & 48.2 & 29.2 & \multicolumn{2}{|r|}{1.8} & 19.0 & 1.8 & 100 & 168 \\
\hline $20-24$ & 24.7 & 29.9 & \multicolumn{2}{|r|}{26.0} & 17.5 & 1.9 & 100 & 154 \\
\hline $25-29$ & 6.4 & 17.3 & \multicolumn{2}{|r|}{50.0} & 24.5 & 1.8 & 100 & 110 \\
\hline $30-34$ & 2.7 & 9.1 & \multicolumn{2}{|r|}{71.8} & 15.5 & 0.9 & 100 & 110 \\
\hline $35-39$ & - & 9.1 & \multicolumn{2}{|r|}{81.8} & 9.1 & 0.0 & 100 & 34 \\
\hline $40-44$ & - & 5.2 & \multicolumn{2}{|r|}{90.5} & 1.7 & 2.6 & 100 & 116 \\
\hline $45-49$ & - & 12.1 & \multicolumn{2}{|r|}{87.9} & - & - & 100 & 33 \\
\hline $50-54$ & - & 4.9 & \multicolumn{2}{|r|}{90.2} & 3.7 & 1.2 & 100 & 82 \\
\hline $55-59$ & - & 7.1 & \multicolumn{2}{|r|}{85.7} & 7.1 & - & 100 & 14 \\
\hline $60-64$ & - & 7.7 & \multicolumn{2}{|r|}{79.5} & 5.1 & 7.7 & 100 & 39 \\
\hline $65+$ & - & 2.7 & \multicolumn{2}{|r|}{66.7} & 16.7 & 13.9 & 100 & 36 \\
\hline Total & 42.9 & 11.8 & \multicolumn{2}{|r|}{33.5} & 10.0 & 1.7 & 100 & $x$ \\
\hline Number & 614 & 169 & \multicolumn{2}{|r|}{479} & 143 & 25 & & 1,430 \\
\hline \multicolumn{9}{|c|}{ Female } \\
\hline & $\begin{array}{l}\text { chil- } \\
\text { dren }\end{array}$ & servants & $\begin{array}{l}\text { household- } \\
\text { ers' wives }\end{array}$ & $\begin{array}{l}\text { independent heads } \\
\text { of households }\end{array}$ & relatives & lodgers & & \\
\hline $0-4$ & 100.0 & - & - & - & - & - & 100 & 193 \\
\hline $5-9$ & 96.9 & - & - & - & 2.1 & 1.0 & 100 & 192 \\
\hline $10-14$ & 73.5 & 12.4 & - & - & 11.2 & 2.9 & 100 & 170 \\
\hline $15-19$ & 49.3 & 24.0 & 5.5 & 0.5 & 16.1 & 4.6 & 100 & 217 \\
\hline $20-24$ & 17.8 & 18.9 & 29.4 & 2.2 & 26.1 & 5.6 & 100 & 180 \\
\hline $25-29$ & 6.3 & 5.4 & 60.4 & 5.4 & 22.5 & - & 100 & 111 \\
\hline $30-34$ & 2.0 & 11.5 & 66.9 & 8.1 & 7.4 & 4.1 & 100 & 148 \\
\hline $35-39$ & - & 2.4 & 80.5 & 9.8 & 7.3 & - & 100 & 41 \\
\hline $40-44$ & 1.1 & 4.3 & 68.1 & 17.0 & 4.3 & 5.3 & 100 & 94 \\
\hline $45-49$ & - & 2.4 & 63.4 & 14.6 & 19.5 & - & 100 & 41 \\
\hline $50-54$ & - & 2.7 & 46.8 & 18.9 & 26.1 & 5.4 & 100 & 111 \\
\hline $55-59$ & - & - & 36.4 & 9.1 & 18.2 & 36.4 & 100 & 11 \\
\hline $60-64$ & - & - & 29.4 & 11.8 & 52.9 & 5.9 & 100 & 34 \\
\hline $65+$ & - & - & 20.0 & 11.4 & 51.5 & 17.1 & 100 & 35 \\
\hline Total & 41.4 & 8.8 & 27.1 & 5.0 & 14.1 & 3.5 & 100 & $x$ \\
\hline Number & 654 & 139 & 427 & 79 & 223 & 56 & $x$ & 1,578 \\
\hline
\end{tabular}

Source: Cezary Kuklo's data bank - List of Trzcianne parishioners from 1843. 
the character of the farm, where there was a higher demand for the hard physical work of men (primarily plowing, harrowing, haymaking etc.) than of women (to a higher degree, work in the garden and the cowshed). It is important to note that the percentage of servants was not stable in the subsequent age groups, and its peak was in men in the 15-19 and 20-24 age groups (29.2\%-29.9\%), whereas in women it was in the $15-19$ age group (24\%). A job as a hired hand or paid female servant in the circumstances of a serf village was neither a discrediting occupation nor a permanent one in most cases but enabled them to earn their own money and gave them a faster start in adult life. ${ }^{37}$ First observations on the basis of an analysis of family names indicate that male and female servants were recruited from householders and their neighbors' relatives. Besides, they had a distinctive demographic characteristic, since $70 \%$ of the men and as many as $77 \%$ of the women in the servant group were young people under 25 , so younger than the average age of marriage. In the first half of the 19th century peasants married on average at the age of 26, and women at 22 (first marriage). Thus, we can assume that service was a stage in the life of young Podlasie peasants before emancipation. The situation was similar in the previous period (until the end of the 18th century) in many other regions of the Polish-Lithuanian Commonwealth, ${ }^{38}$ not to mention Western Europe. ${ }^{39}$

In the data in columns two, three and four of Table 3, we can see the dependence between the fall in the proportion of children and the growth in the proportion of male hands and female servants as well as between the age of assuming the function of householder and the fall in the percentage of hired servants. Adulthood

${ }^{37}$ Tomasz Wiślicz, Upodobanie. Matżeństwo i zwiazki nieformalne na wsi polskiej XVIIXVIII wieku (Wrocław: Wydawnictwo Chronicon, 2012), 59. For more on domestic service and its amount in pre-industrial Europe, see Antoinette Fauve-Chamoux, ed., Domestic Service and the Formation of European Identity. Understanding the Globalization of Domestic Work, 16th-21st Centuries (Bern: Peter Lang, 2004).

${ }^{38}$ See Kopczyński, Studia, 119-137; Szołtysek, Rethinking, 319-401, points out considerable differences in the scale of the number of servants between the regions, the highest being in the West of Poland (over 13\% of the whole population and present in over $39 \%$ of households) and the land of Belarus and northern Ukraine (not more than $2.5 \%$ of the population and $10 \%$ of households), 329-331.

${ }^{39}$ Peter Laslett, "Characteristics of the Western Family Considered Over Time," in: Peter Laslett, Family Life and Illicit Love in Earlier Generations. Essays in Historical Sociology (Cambridge: Cambridge University Press, 1997), 12-49; Ann Kussmaul, Servants in husbandry in early-modern England (Cambridge: Cambridge University Press, 1981); Michael Mitterauer, "Servants and Youth," Continuity and Change 5 (1990), 1: 11-38; Antoinette Fauve-Chamoux, "Pour une histoire européenne du service domestique à l'époque préindustrielle," in : Le phénomène de la domesticité en Europe, XVIe-XXe siècles, eds. Antoinette Fauve-Chamoux, Ludmila Fialová (Praha: Česká Demografická Společnost Sociologicý Ústav AV ČR, 1997), 57-73; Frans van Poppel, Michel Oris, "Introduction," in: The Road to Independence. Leaving Home in Western and Eastern Societies, 16th-20th Centuries, eds. Frans van Poppel, Michel Oris, James Lee (Bern: Peter Lang, 2004), 1-29. 
combined with marriage and taking control over the household in Podlasie villages in the declining phase of late serfdom actually occurred in men after the age of 25. In the 25-29 and 29-34 age ranges married men made up, respectively, 50\% and nearly $72 \%$, although some of them started their families a little earlier: $26 \%$ at the age of 20-24. The share of men who were heads of households increased proportionally with their age and was the highest in the range $50-54$, at over $90 \%$. However, what is most conspicuous is the high percentage of old men as heads of households. As many as two thirds of men aged 65 and older were still managers of their own households. The data seem to be evidence that peasants sought to remain in the position of householder for as long as possible. They realized that with passing the household to a younger descendant their social and economic status would be reduced. A radical change in the social status of elderly people at the moment of ceding the land to the children and their transition from "dożywocie" (life annuity) into a worse position, both in the closest small family group as well as in the larger community of the whole village, is testified by numerous ethnological studies. ${ }^{40}$

Among women, marriage and taking the position of mistress of the house was similar to those of men, even though by the time they were 40 , a tenth of them had to manage the household alone, either due to her husband's conscription into the tsar's army or because of his death. Women usually became heads of their households at the age of 40-54. Generally, however, the share of women as heads of household in the Podlasie village was not very high, since they managed 79 out of 558 households (14.2\%). Most of these, over 68\%, were landless households.

Previous, scarce, studies on peasants' life cycle to the end of the 18th century showed that relatives in the household were usually old people. ${ }^{41}$ However, among the dwellers of peasants' cottages in the villages of northern Podlasie (14.1\% women and $10 \%$ men) very few counted as the oldest residents, at least in reference to men. From 143 relatives, as many as 126 men (88\%) were under 35, whereas the share of 60 year-olds and older was a mere $5.6 \%$. In contrast, female relatives followed a different demographic pattern. Only 141 out of 223 , i.e., $63.2 \%$ were young women under 35 , while $16.1 \%$ were old women of 60 and above. In the Trzcianne peasant community, relatives were usually unmarried siblings of the

${ }^{40}$ See Danuta Markowska, "Z problematyki zmian struktury rodziny (rodzina wielopokoleniowa a ludzie starzy)," in: Zmiany kultury chtopskiej. Problematyka i metody prac etnograficznych, ed. Kazimiera Zawistowicz-Adamska (Wrocław: Zakład Narodowy im. Ossolińskich, 1973), 156; Woźniak, Kultura, 114; Bartłomiej Gapiński, Ludzie starzy na wsi polskiej od schyłku XIX wieku po rok 1939 (Poznań: Wydawnictwo Nauka i Innowacje, 2014), 100-102. Leon Dyczewski expresses a dissenting opinion, see Ludzie starzy i starość w spoteczeństwie i kulturze (Lublin: Redakcja Wydawnictw KUL, 1994), 15. According to him, old people in Christianized Europe occupied a high social position and enjoyed great prestige.

${ }^{41}$ Kopczyński, Studia, 150-153. 
householder and the mistress of the household (53 households), married children in the households of the parents or parents-in-law (45 households); both parents of the householder and his wife ( 31 households), as well as the mother and the mother-in-law of the householder (4 households). The share of other ascending relatives (uncles, aunts) and descending relatives (nephews) was merely symbolic.

In addition, so-called katnicy (sing. kątnik, a landless lodger) were, although relatively seldom, members of peasant households in the early $1840 \mathrm{~s}$. Women (3.5\%) were represented in this role twice as often as men (1.7\%). As seen in Table 3, they were a very diverse group in terms of age. Looking at their demographic profile, where over half of the men and nearly $59 \%$ of the women were in their prime, since they had not turned 40 , we can risk the hypothesis that they added to the workforce in the household. In contrast to paid servants, they could work for bed and board only. Only $32 \%$ of lodger men and $14.3 \%$ of lodger women were old people $(60+)$.

\section{Twenty years after the abolition of serfdom}

In the early 1880 s, peasant households functioned in new legal and economic circumstances. First of all, peasants were personally free; they could leave their family home in search of better living conditions. Money was of increasing importance in their lives, for it was necessary to pay installments related to buying out the land, taxes or purchasing a new plot of land. Many years after the affranchisement, land still remained an omnipotent value in the socio-economic life of villagers, and its possession was a major determiner for not only concluding a marriage, but also economic trips taken by both young unmarried men, and even mature heads of the family. ${ }^{42}$

It is important to underscore that Podlasie peasants, as in other western governorates of the Empire, purchased land at considerably reduced prices, for work on the master's field was exchanged for a $20 \%$ reduction in rent. Moreover, the basis for calculating the buyout of the land value was the quality of the soil, so the rule was fairer for the peasant than the renter in accordance with the reform of $1861 .{ }^{43}$ The emancipation reform in private villages of the Białystok Oblast resulted in the structure of self-sustainable farm-households, because farms over 10 tithes (over 19.5 morgens), recognized as self-sustainable, made up over $62 \%$ of the total, and made up as much as $85 \%$ of the total area of peasant farms around $1870 .{ }^{44}$

${ }^{42}$ Markowska, Rodzina wiejska, 200; Markowska, Rodzina w społeczności wiejskiej, 128129; Jadwiga Kucharska, "Stosunek do ziemi jako podstawy bytu mieszkańców wsi kujawskiej (wstępne wyniki badań z 1970 r.)," in: Zmiany kultury chłopskiej, 225-226.

${ }^{43}$ Szumski, "Uwłaszczenie," 26-27.

${ }^{44}$ Ibidem, 35, Table 1. 
Some of the families functioning at that time had been started before the emancipation, while some of them were started after the reforms of the years 1861-1863. Did the socio-economic transformations (development of the notvery-distant Białystok industrial district) have any impact on the previous behavior of individuals in terms of marriage, which was of key importance for the founding and functioning of peasants' households?

The data in Table 4 referring to the position of an individual in a household in 1882 show two very important issues. In comparison with 1843 , one can see a clear growth in the percentage of children, from $42.2 \%$ to $53.8 \%$, who even today make up the most numerous groups of residents. However, the growth did not refer to the same degree to all age groups but primarily occurred in three ranges: e.g., 10-24, so it concerned older children and young people. This was by no means a result of the higher fertility of mothers, who had already given birth via natural fertility, but was due to no occurrence of young people as hired workers. We may hypothesise that in the new economic situation, it ceased to be profitable for the previous householders to employ paid staff in the form of male hands or female servants. This loss of workforce could be compensated to a certain degree by keeping adult sons a little longer at home, since at 20-24 only slightly above $15 \%$ were heads of their own households in comparison with $26 \%$ in 1843 . Above 25 years of age, peasants' sons (including their remarriages) were starting families even faster than 40 years previously. However, what is striking is the not inconsiderable share of old men among heads of household. If, before the emancipation, the proportion of householders had clearly shrunk when they turned 55 , this was now occurring ten years later. However, even if they had turned 65, nearly $92 \%$ of them still remained heads of their households.

In the first two decades after emancipation, peasants' daughters over the age of 20 married even more frequently than in the previous period, the evidence of which are the percentages of mistresses of the household in the subsequent age ranges. In comparison with the period of serfdom, they became independent managers of households only at a later age, when they turned 55. In the 55-59 and 60-64 age ranges, independent female heads of household constituted over $14 \%$ of women in these age groups. Nevertheless, the post-emancipation period is characterized by the progressive diminishing in importance of single women farmers. In 1882 they managed only $7 \%$ of all farm households.

Even though in the early 1880 s, the group of relatives decreased to $6.3 \%$ in men and $11.2 \%$ in women, the demographic profile of the group of men, which is worth noting, remained the same. Among them, young people still dominated (72\% under $35,82 \%$ under 40 ), and the percentage of old men was minimal, a mere $3.7 \%$. More significant changes occurred among women, for the percentage of young 
women shrank clearly from $63.2 \%$ in 1843 to $46.3 \%$ in 1882 , with a simultaneous growing share of old women from $16.1 \%$ to $27.9 \%$.

Among relatives, as in the previous period, most common were the unmarried siblings of the householders and their wives (52 households); the householder's mother and mother-in-law (45 households); married children in their parents and parents-in-laws' households (39 households), both the householder and his wife's parents ( 22 households), as well as the householder's father and father-inlaw (6 households).

The share of lodgers as members of peasants' households, small (2.7\%) before the emancipation, became even more insignificant after the agrarian reforms in the early $1860 \mathrm{~s}$, since both sexes jointly made up fewer than $0.5 \%$ of the residents.

\section{Before the outbreak of World War I}

At the beginning of the 20th century, peasant family members in Trzcianne no longer knew the reality of serfdom. At most, they could have heard of it from the few remaining members of the oldest generation. Instead, they saw changes in the rural areas of the Grodno Governorate (although not as intense as in the Kingdom of Poland), the progressive territorial mobility of their neighbors, including economic emigration; they had begun to use transport on roads and railroads, and had certainly heard of, or perhaps even been to, the dynamically developing Białystok, the leading town in the whole region and an industrial center, the population of which reached approximately 82,500 in $1910 .{ }^{45}$

Comparing the data in Table 5 for the year 1910 with the data from nearly 30 years previously (Table 4), more similarities than fundamental differences can be seen. Among children, still the most numerous group among the residents (56.7\%), there were few people who had never married and had remained single. What attracts the attention is the slower pace of starting families. In 1882, at the age of 20-24, every sixth man, and in the next age group (25-29) every other man, was the head of his own household. In 1910, heads of household in the same age groups were, respectively, only $9 \%$ and nearly $41 \%$ of men. The share of householders grew systematically up to the age of $55 \mathrm{in} \mathrm{men,} \mathrm{and} \mathrm{the} \mathrm{fall} \mathrm{in} \mathrm{the}$ proportion in subsequent years occurred at the cost of an increase in the percentage of relatives. Worth noting is that heads of household in the Podlasie village remained in that position for longer, because the share of old householders of 65 and more increased up to nearly $93 \%$.

${ }^{45}$ Adam Dobroński, Białystok. Historia miasta (Białystok: Zarząd Miasta Białegostoku, 2001), 91 - c. $66 \%$ were Jews, $18.2 \%$ Poles, $7.8 \%$ Russians, $5.8 \%$ Germans and $2 \%$ Belarussian. 
Table 4. Peasants by their status in the household in Trzcianne parish, $1882(\%)$

\begin{tabular}{|c|c|c|c|c|c|c|c|}
\hline Age & \multicolumn{5}{|c|}{ Status in the household } & Total & Number \\
\hline \multicolumn{8}{|c|}{ Male } \\
\hline & children & \multicolumn{2}{|c|}{ heads of household } & relatives & lodgers & & \\
\hline $0-4$ & 100.0 & \multicolumn{2}{|c|}{-} & - & - & 100 & 295 \\
\hline $5-9$ & 99.6 & \multicolumn{2}{|r|}{-} & 0.4 & - & 100 & 263 \\
\hline $10-14$ & 95.8 & \multicolumn{2}{|r|}{-} & 3.8 & 0.4 & 100 & 240 \\
\hline $15-19$ & 88.1 & \multicolumn{2}{|r|}{2.0} & 9.5 & 0.4 & 100 & 253 \\
\hline $20-24$ & 69.0 & \multicolumn{2}{|r|}{15.2} & 15.8 & - & 100 & 184 \\
\hline $25-29$ & 31.6 & \multicolumn{2}{|r|}{51.3} & 17.1 & - & 100 & 117 \\
\hline $30-34$ & 8.1 & \multicolumn{2}{|r|}{82.2} & 9.6 & - & 100 & 135 \\
\hline $35-39$ & 2.7 & \multicolumn{2}{|r|}{83.2} & 12.4 & 1.8 & 100 & 113 \\
\hline $40-44$ & 0.8 & \multicolumn{2}{|r|}{93.6} & 5.6 & - & 100 & 125 \\
\hline $45-49$ & 1.1 & \multicolumn{2}{|r|}{92.4} & 5.4 & 1.1 & 100 & 92 \\
\hline $50-54$ & - & \multicolumn{2}{|r|}{96.1} & 3.9 & - & 100 & 103 \\
\hline $55-59$ & - & \multicolumn{2}{|r|}{94.3} & 3.8 & 1.9 & 100 & 53 \\
\hline $60-64$ & - & \multicolumn{2}{|r|}{98.4} & 1.6 & - & 100 & 64 \\
\hline $65+$ & - & \multicolumn{2}{|r|}{91.7} & 6.0 & 2.3 & 100 & 84 \\
\hline Total & 56.1 & \multicolumn{2}{|r|}{37.2} & 6.3 & 0.4 & 100 & $x$ \\
\hline Number & 1,190 & \multicolumn{2}{|r|}{789} & 134 & 8 & $\times$ & 2,139 \\
\hline \multicolumn{8}{|c|}{ Female } \\
\hline & children & $\begin{array}{l}\text { householders' } \\
\text { wives }\end{array}$ & $\begin{array}{l}\text { independent heads } \\
\text { of household }\end{array}$ & relatives & lodgers & & \\
\hline $0-4$ & 100.0 & - & - & - & - & 100 & 287 \\
\hline $5-9$ & 97.5 & - & - & 2.5 & - & 100 & 276 \\
\hline $10-14$ & 94.7 & - & - & 5.3 & - & 100 & 226 \\
\hline $15-19$ & 91.9 & 2.3 & - & 5.9 & - & 100 & 221 \\
\hline $20-24$ & 49.7 & 32.5 & 0.5 & 16.8 & 0.5 & 100 & 197 \\
\hline $25-29$ & 12.9 & 70.2 & 1.7 & 14.6 & 0.6 & 100 & 178 \\
\hline $30-34$ & 6.1 & 76.2 & 4.9 & 12.2 & 0.6 & 100 & 164 \\
\hline $35-39$ & 5.3 & 85.8 & 3.5 & 5.3 & - & 100 & 113 \\
\hline $40-44$ & - & 85.5 & 4.8 & 8.9 & 0.8 & 100 & 124 \\
\hline $45-49$ & - & 82.9 & 5.7 & 11.4 & - & 100 & 70 \\
\hline $50-54$ & - & 65.2 & 8.7 & 26.1 & - & 100 & 92 \\
\hline $55-59$ & - & 61.4 & 14.0 & 22.8 & 1.8 & 100 & 57 \\
\hline $60-64$ & - & 38.6 & 14.3 & 44.3 & 2.9 & 100 & 70 \\
\hline $65+$ & - & 18.6 & 11.9 & 61.0 & 8.5 & 100 & 59 \\
\hline Total & 52.0 & 33.4 & 2.8 & 11.2 & 0.6 & 100 & $x$ \\
\hline Number & 1,110 & 713 & 59 & 240 & 12 & $x$ & 2,134 \\
\hline
\end{tabular}

Source: Cezary Kuklo's data bank - List of Trzcianne parishioners from 1882. 
Table 5. Peasants by their status in the household in Trzcianne parish, 1910 (\%)

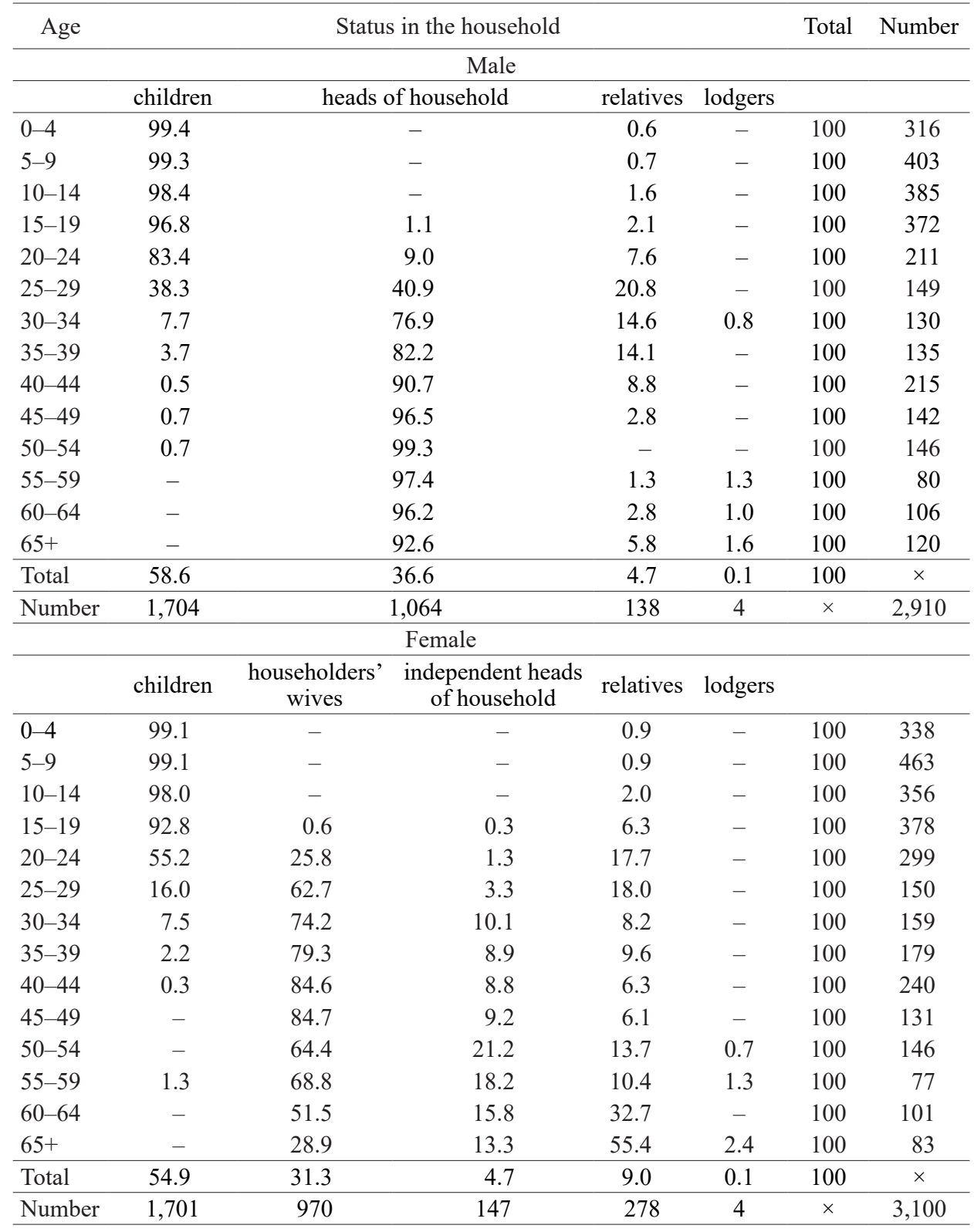

Source: Cezary Kuklo's data bank - List of Trzcianne parishioners, 1910. 
Among women, over a quarter at 20-24 had married and achieved the status of householder's wife, while in the next age range (25-29) nearly two thirds were in this situation (almost 63\%). The highest share of mistresses of the household were in the 40-50 age group, and after that, some of them had to manage the household alone. It is worth noting that whereas in the initial period following emancipation, the percentage of women's households reduced to $7 \%$, and independent mistresses of the household were a mere $2.8 \%$ of the whole female population, in the first decade of the 20th century they managed $12.1 \%$ of all households in the village, while constituting $4.7 \%$ of all women.

The number of relatives of both sexes who were members of peasants' households declined further, to $4.7 \%$ of men and $9.0 \%$ of women. In comparison with the previous period, there were no significant changes in this group. Young men under $35(61.6 \%)$ still prevailed, although the percentage of the oldest men had nearly doubled from $3.7 \%$ to $7.2 \%$. Among women, the proportions of young and old relatives remained at a very similar level in comparison with the years 1882 , at $47.1 \%$ and $28.4 \%$ respectively.

\section{Discussion}

In the light of the date referred to, there is no doubt that the agrarian reforms in Russia carried out in the years 1881-1863 affected, although not immediately, the lives of families and thereby transformations in the social structure of the village in the western part of the Grodno Governorate ${ }^{46}$ The most important change in the social structure of the rural population was the decrease in the importance of servants in the peasant economy after the abolition of serfdom, which

${ }^{46}$ In Matti Polla's opinion, the emancipation of peasants in Russia had a major impact on the family system, for the "agrarian-oriented family system" in the 1830s (marriages were concluded at a very young age, multi-generation households made up two thirds of the total, there was absolutely no household without a married couple, complex households constituted $80 \%$ of the total, the average size of the household was 8 people), changed into the "handicrafts, trade and suburban family system" (marriages after the age of 20 ; over $85 \%$ of women and over $90 \%$ of men married before $30,9 \%$ of households did not include a married couple, $19 \%$ were complex households, and average size was 4.8 people), see Polla, "Family," 42. Among more recent works it is worth quoting Boris N. Mironov's opinion ("Long-Term Trends in the Development in Christian Russia from the Sixteenth to the Twentieth Centuries: An Analytical Overview of Historiography," Journal of Family History 41 (2016), 4) that from the 18th century to the mid-19th century, in many regions of Russia the percentage of extended and complex peasant families showed a rising trend and they dominated among the whole population (361-363), whereas after the abolition of serfdom the percentage of simple families grew and the average size of household was reduced (365). However, Mironov observes that in Russia it is difficult to consider serfdom as the reason for the occurrence of complex families, for after its abolition the increase in the share of simple families was not rapid but slow and gradual: Mironov, "Long-Term Trends," 370. 
now functioned in the market economy. By the second decade after emancipation it is difficult to find paid servants in peasants' households recruited from sons and daughters, the children of closer and more remote neighbors, the majority of whom were now staying longer in their parents' home. This is clearly visible in the data in Table 6, which shows the pace at which children left their parents' households before and after emancipation. Following Richard Wall, we identify the index with the pace of children leaving their parents' households, even though it is obvious that it also provides us with the number of children remaining in their parents' home ${ }^{47}$ It represents rates of the simple index, the basis of which is the number of children aged 5-9. Clear disproportions in older age groups above the age of 10 cannot be explained with mortality, like the decrease in the groups of $0-4$ and $5-9$, since they are primarily evidence of leaving family homes and joining the ranks of servants. In 1843, in Podlasie villages, the pace that younger children in the group of 10-14 year-olds left home was not very fast, affecting only $18 \%$ of boys but as many as $33 \%$ of girls, who even until the beginning of the 20th century always, and this is worth emphasizing, left their parents' households earlier. A clear acceleration occurred in the next two age groups: index 51 in the group of 15-19 year-olds, and even 24 in the group of 20-24 year-old men, as well as, respectively, index 58 and 17 in women. We have already mentioned the convergence between leaving parents' houses and the growth in the proportion of servants (see Table 3).

Table 6 . The rate at which children left their family home in Trzcianne parish, 1843-1910

\begin{tabular}{lrrrrrr}
\hline & \multicolumn{2}{c}{1843} & \multicolumn{2}{c}{1882} & \multicolumn{2}{c}{1910} \\
\cline { 2 - 7 } Age & male & female & male & female & male & female \\
\cline { 2 - 7 } & 100 & 100 & 100 & 100 & 100 & 100 \\
\hline $5-9$ & 82 & 67 & 88 & 80 & 95 & 76 \\
$10-14$ & 51 & 58 & 85 & 75 & 90 & 76 \\
$15-19$ & 24 & 17 & 48 & 36 & 44 & 36 \\
$20-24$ & 4 & 4 & 14 & 9 & 24 & 5 \\
$25-29$ & 2 & 2 & 6 & 6 & 5 & 4 \\
$30+$ & \multicolumn{7}{c}{ Indexes } \\
\hline
\end{tabular}

Source: Cezary Kuklo's data bank - List of Trzcianne parishioners from 1843; List of Trzcianne parishioners from 1882; List of Trzcianne parishioners from 1910.

\footnotetext{
${ }^{47}$ Here we use the method applied by Richard Wall in "Leaving Home."
} 
After emancipation, the pace at which the younger generation left their parents' household was not only slower, but over the years 1882-1910, there was a tendency to postpone the very moment of leaving. The index of decrease in boys in the 15-19 age group, which came to 51 before emancipation, was 85 in 1882, whereas in 1910, it was 90. In the next group, 20-24, its values were respectively $24-48$ and 44 . Similarly peasants' daughters also left the family home more slowly.

In the western villages of the Grodno Governorate after emancipation, being a servant ceased to be a stage in the life of the young, which resulted in this group vanishing by the early $1880 \mathrm{~s} .{ }^{48}$ When we describe the phenomenon we cannot omit an important question, which was, both before and after emancipation, the demand for labor. Whereas before emancipation, peasants doing a high amount of work in serfdom compensated for a deficit of labor by employing male hands and female servants, after the agrarian reforms they tried to keep their adult children a few years longer, postponing their becoming independent. It is important to note that in 1843, in the 20-24 age group, $26 \%$ of men were already householders, while in the next decade this number was exactly 50\%, whereas in 1910 the proportions were, respectively, $9 \%$ and nearly $41 \%$. It also seems possible to accept that in certain households, instead of permanent servants present throughout the year, the household workforce would be supplemented by farmworkers employed on a daily basis at harvest time. This was primarily men and, to a lesser degree, women. Some of them could have come from the landless population, although the number of landless households was quite considerably reduced, but only at the beginning of the 20th century (1844: $28.1 \%$; 1882: 26.6\%; 1910: $12.2 \%$ ). Here, the point was to minimize the expenses connected with the year-round maintenance of servants. On the other hand, we know that noble neighbors tried to employ waged workers on their farms, for example, from the beginning of April until the end of harvest, but not in the period of late fall and winter. ${ }^{49}$

${ }^{48}$ The reduction of servants in peasant households in the second half of the century is observable in Western Europe, for example in England: see Sheila McIsaac Cooper, "From Family Member to Employee: Aspects of Continuity and Discontinuity in English Domestic Service, 1600-2000," in: Domestic Service and the Formation of European Identity. Understanding the Globalization of Domestic Work, 16th-21st Centuries, ed. Antoinette Fauve-Chamoux (Bern: Peter Lang, 2004), 288-289; but also in Czech Lands: see Ludmila Fialová, "Domestic Staff in the Czech Lands as the Turn of the 19th and 20th Centuries in the Light of Statistical Figures," in: Domestic Service, 148.

${ }^{49}$ Eryk Kotkowicz, "Wieś i dwór podlaski z przełomu XIX i XX wieku w świetle wspomnień i pamiętników," in: Wolni i uwłaszczeni. Chłopi a przemiany społeczno-gospodarcze i polityczne w Europie Wschodniej w XIX i na poczatku XX wieku, ed. Dorota Michaluk (Ciechanowiec: Muzeum Rolnictwa im. ks. K. Kluka w Ciechanowcu - Urząd Marszałkowski Województwa Podlaskiego, 2017), 93-94. 
When considering the impact of the reforms, we cannot ignore the fate of old people in the rural environment, which was highly diverse if we consider their sex. Over the years 1843-1910 one can see a big group, still growing in the subsequent lists, of elderly householders aged 65 and above. If, before emancipation, householders made up only two thirds of all men over 65, in 1910 they constituted nearly $93 \%$. Of course, the proportions of householders' wives also grew from $20 \%$ to nearly $29 \%$, and, to a lesser extent, independent female heads of household, from $11.4 \%$ to $13.3 \%$. This demonstrates a peculiar calculation of the householders to remain as long as possible in the position achieved in the hierarchy of the rural community. Also, at the beginning of the 20th century, they were convinced that passing the management of the household on to younger hands (the son or son-inlaw's) was tantamount to a visible decrease in prestige and a less secure fate in the future. It is important to add that old age had two different faces. It changed less in men's lives. In 1843, they mostly (almost 67\%) still managed their households, nearly $17 \%$ were relatives in the household of married children, and less than $14 \%$ were put up at strangers' houses. At the same time, nearly a third of old women acted as the householder's wife or managed the household alone. They were relatives in the family of their married children three times as often as men (51.5\%), and one in six of them was a lodger. Almost half a century after emancipation, old male peasants had visibly increased their presence in the group of householders and only a few of them lived the life of a relative. Indeed, the joint percentage of householders' wives and independent female heads of household rose from $31.4 \%$ to $42.2 \%$, but still over a half of them $(55.4 \%)$ lived as a relative. At the same time, the number of female lodgers was obviously reduced, since the percentage decreased from $17.1 \%$ in 1843 to a mere $2.4 \%$ in 1910 .

The decreasing number of the 'relatives' group in the years 1843-1910, from $12.2 \%$ to $6.9 \%$, allows us to hypothesize that there was a progressing nuclearization of family units, resulting in the reduction of the share of extended and complex households, which may be modest evidence of the modernizing attitudes of Podlasie peasants. Simultaneously, this would mean a breakthrough in the previous caring function of the rural family, which earlier had secured assistance and care for the old members of the households who were not able to cope by themselves. In our opinion, emancipation also strengthened the status of the head of the household, who now became its legal owner, and was thus much more powerful than in the previous period. Thereby, he could have a stronger impact on the younger generation, since he had more material resources for transferral or division, even though, in a way, he had to take into consideration the rules of inheritance. However, in the new legal and economic situation, the place of relatives (especially those more distant) as cohabitants became insecure. First observations of the structure of the Trzcianne peasants' household structure with the 
use of Peter Laslett's typology demonstrate a growth in the percentage of simple households from nearly $66 \%$ to nearly $76 \%$, with a simultaneous reduction in the share of the families of extended and complex structure from almost $31 \%$ to $22 \%$.

In the context of our data based on over 1,200 peasant households, the sociologist Danuta Markowska's hypothesis outlined forty years ago, based on the observation of the communities of two villages, Chrołowice and Wólka Zamkowa (nearly 30 farms each), that "the patriarchal multi-generation family was only a transient phenomenon, characteristic of the phase of transformation from feudal to capitalistic relations in agriculture," can hardly be recognized as referring to all Podlasie villages located in the western part of the Grodno Governorate. In the period $1880-1900$, the percentage of multi-generation families was $55 \%$ in Chrołowice and $32 \%$ in Wólka Zamkowa. ${ }^{50}$

In light of the previous deliberations, even though without final establishments in terms of the size of families depending on the sex and age of the head of the household, it is, however, worth trying to answer the question: Was the individual's life cycle connected with peasants' family strategies in Podlasie villages located in the western part of the Grodno Governorate in the 19th century and the beginning of the 20th century more similar to the Russian model or did it reflect the qualities of the West or Central European model $?^{51}$ Seeing the considerable presence of life cycle servants, and then their disappearance after emancipation, ${ }^{52}$ the stable age of men's marriages throughout this period (26), and of women (22) (thus, older than the age of peasants in ethnic Russian lands ${ }^{53}$ ), a low percentage of relatives in the population, as well as marriage being an important element in

${ }^{50}$ Markowska, Rodzina wiejska, 195.

${ }^{51}$ Peter Laslett, "Family and Household as Work Group and Kin Group: Areas of Traditional Europe Compared," in: Family Forms in Historic Europe, eds. Richard Wall, Jean Robin (Cambridge: Cambridge University Press, 1983), 518. He described the characteristics of the population and family households in modern Europe from many perspectives: demographic, the foundation of a new household, family composition, and the productive and caring functions of the household. However, Plakans, "Agrarian," 78, like many other authors, points out that within the loosely determined regions, including the eastern zone, we cannot rule out considerable fluctuations in the functioning of households.

${ }^{52}$ In peasants' households in central Russia there were no servants and hands, for whom work, like in the West, was a traditional stage in the life of a young person. See Plakans, "Agrarian," 83.

${ }^{53}$ The issue of comparative studies in the case of the Romanov empire is not simple due to its size, and the age at marriage of peasants (both men and women) in Russia was diverse. In the southern part, in the Elary of the 1830s, in Mishino, men were on average 18.7 years old at marriage; women 19.4; in the central part, in Voshchaznikovo, 25.5 and 20.7 respectively; and this did not change very much in the 1880 s, which can be seen in the data for the village of Drakino: bachelors were 21.2 and maids 20.7: see Polla, "Family," 29, 35. See also the family characteristics of Eastern Europe in Plakans, "Agrarian," 77-80. It is enough to remind ourselves that Laslett primarily considered the low percentage of those marrying as one of the characteristic qualities of the Central European model, whereas later works demonstrated that marriage was common in the region whereas celibacy was not. 
founding a household, there are definitely more similarities to the model of peasants' households in Central Europe than those in the East.

In this similarity of the Podlasie village to other rural communities in Central Europe, the high percentage of simple households and relatively low percentage of extended and complex households, which in the Russian model exceeded at least a half of all, also cannot be ignored. ${ }^{54}$

\section{Conclusion}

The data presented in the paper allow us to draw, with high probability, the following conclusions on the trend in the life cycle of peasants in the village under serfdom and after their emancipation, including their sexes. In the first period, childhood ended relatively soon, usually after 10 years of age, since a group of older boys were hired as paid workers. For the subsequent 10 years an increasing group of them joined the ranks of servants, because being a servant was not a discrediting occupation and for most of them it was just a transitional stage of life. A more serious change in Podlasie serfs' lives occurred at around 30 years of age. The group of unmarried men diminished, like the group of servants, and half of the men managed the household, which they passed to the younger generation after they turned 55. Men acted as relatives more seldom than women; they were mostly young and able to work hard, which enriched the household workforce.

Women's life cycle had the same stages as their brothers', even though it was moved in time. Also, peasants' daughters, when older, found paid jobs as servants and left their parents' households sooner than their brothers, which was also related to their earlier marriage. However, after 40, they experienced widowhood more often than men, which was usually tantamount to becoming an independent head of the household. In the village, under serfdom, they managed every seventh household. Most of them lived modest lives. Over a half were housed as relatives with the families of their married children, and almost one in five lived until their death renting at strangers' houses.

${ }^{54}$ In the early 1830 s in southern Russia complex households alone made up over $74 \%$ (Mishino), in the central part over $80 \%$ (Manuilovskoe) but only 19\% in Voshchaznikovo. After emancipation, in fact, the percentage of complex households was reduced to nearly $26 \%$ in Kostromma, to over $42 \%$ in Drakino, but including extended families, more complex structures still made up c. $43 \%-66 \%$ of all households: compare Polla, "Family," 29, 35. Currently, the broadest characteristics of family structures in different regions of Russia from the 16th century to the beginning of the 20th century can be found in Mironov's book: see Boris N. Mironow, Rossijskaja imperija: ot tradicii k moderny, vol. 1 (Sankt Peterburg: Sankt-Peterburgskij Gosudarstwiennyj Uniwersitet, 2014). 
Nearly half a century after emancipation, at the threshold of the 20th century, peasants' sons remained in their parents' households for much longer, with certain exceptions until the age of 25 . The changed economic and legal circumstances of the functioning of the peasant household after the agrarian reforms forced them to abandon the family home, which was tantamount to the elimination of the customary second stage in their lives, i.e., temporary manual work. Assuming the position of head of the household took place slightly later than during serfdom, but they also remained longer in this position, practically until the age of 65. Throughout their lives, most of the Podlasie peasants independently managed their own household, for they hardly ever lived as relatives with the families of their married children.

Peasants' daughters, like their brothers, did not experience temporary work as female servants and until the age of 20 they remained in their parents' household. They started their own family as a result of marriage within the following 10 years of life. Only after 50, i.e., ten years later in comparison with the period of serfdom, did they more often become heads of households, as a result of their husbands' death. They were independent managers of every eighth peasant household. Towards the end of their lives, having turned 65 , their social situation was far worse than that of men at the same age, but slightly better than that of their grandmothers in the last decades of serfdom. A half of them lived their final years with their married children, but over $42 \%$ were either householders' wives or independent heads of households.

In the light of the materials used, it seems justified to detect an atomization of Podlasie peasant families at the turn of the 20th century, and the fact that the fundamental elements of the family system of Podlasie peasants living in the Grodno Governorate were more similar to Western Europe than Russia. It is important, however, to emphasize that in the light of newer literature on the subject, both European and Russian family patterns were not always as homogeneous as they had been perceived as late as half a century ago (e.g., John Hajnal, or the early works of Peter Laslett).

We would like to do further research on marital behaviors and arranging the foundations of peasant and petty nobility households in Podlasie in the 19th century and the first decades of the 20th century in the broader economic, social and environmental context. This should allow us to not only include the influence of different external factors, but also to scrutinize their mutual effect on each other. ${ }^{55}$ For, as Andrejs Plakans observes, "Historical research has been far more successful in describing changes in family characteristics quantitatively

\footnotetext{
${ }^{55}$ Mironov, "Long-term Trends," 371, also points this out, underscoring the joint effect of social, economic, legal and psychological factors on the family structure.
} 
than in explaining what provoked them." ${ }^{956}$ It would also be desirable to continue the research with a greater amount of data for other territories of the former Polish-Lithuanian Commonwealth.

This is important, as the shelves in the church archives contain hundreds of parish nominative registers of the faithful compiled in the 19th century and at the beginning of the 20th century. Even though they are not perfect sources, through their uniform method of providing data they allow us to very well apply research methods from the arsenal of humanities and social sciences, such as the Laslett-Hammel method employed by us, due to which we can go deeper into family life, the basic group of the rural community, and into its manifold and multi-dimensional determinants in the late feudal and post-affranchising period.

\section{Bibliography}

\section{Primary Sources}

Archdiocese Archives in Białystok. Archives of the Roman Catholic parish in Trzcianne, List of parishioners from 1843; List of parishioners from 1882; List of parishioners from 1910.

\section{Secondary Sources}

Executorium Decretum De Limitibus Dioecesis Vilnensis Latum ab Illustrissimo et Reverendissimo Domino Matropolitano Ignatio Hotowiński. Vilnae 1854.

Wernerowa, Wiesława. "Opisy parafii dekanatu augustowskiego z roku 1784." Studia Podlaskie 4 (1993): 161-239.

\section{References}

A'Hearn, Brian, Joerg Baten, Dorothee Crayen. "Quantifying Quantitative Literacy. Age Heaping and the History of Human Capital." Journal of Economic History 69 (2009), 3: $783-808$.

Baranowski, Bohdan. Życie codzienne wsi między Warta a Pilica. Warszawa: Państwowy Instytut Wydawniczy, 1969.

Bończa-Tomaszewski, Nikodem. "Polskojęzyczni chłopi? Podstawowe problemy nowoczesnej historii chłopów polskich.” Kwartalnik Historyczny 112 (2005), 2: 91-111.

Borowski, Stanisław. Rozwarstwienie wsi Wielkopolskiej w latach 1807-1914. Studium statystyczne nad społecznymi i ekonomicznymi następstwami właczenia wsi w orbite rynku. Poznań: Rada Naukowo-Ekonomiczna przy Prezydium WRN w Poznaniu, 1962.

Chałasiński, Józef. Młode pokolenie chłopów. Procesy i zagadnienia kształtowania się warstwy chtopskiej w Polsce. Warszawa: Państwowy Instytut Kultury Wsi, 1938.

\footnotetext{
${ }^{56}$ Plakans, "Agrarian,” 76.
} 
Crayen, Dorothee, Joerg Baten. "New Evidence and New Methods to Measure Human Capital Inequality before and During the Industrial Revolution. France and the US in the Seventeenth to Nineteenth Centuries." Economic History Review 63, (2010), 2: $452-478$.

Cuisenier, Jean, ed. The Family Life Cycle in European Societies. Hague: Mouton de Gruyter, 1977.

Dobroński, Adam. Białystok. Historia miasta. Białystok: Zarząd Miasta Białegostoku, 2001.

Dobroński, Adam, ed. Historia województwa podlaskiego. Białystok: Instytut Wydawniczy Kreator, 2010.

Dyczewski, Leon. Ludzie starzy i starość w społeczeństwie i kulturze. Lublin: Redakcja Wydawnictw KUL, 1994.

Fauve-Chamoux, Antoinette. "Pour une histoire européenne du service domestique à l'époque préindustrielle." In: Le phénomène de la domesticité en Europe, XVIeXXe siècles, eds. A. Fauve-Chamoux, L. Fialovàà, 57-73. Praha: Česká Demografická Společnost Sociologický Ústawv AV ČR, 1997.

Fauve-Chamoux, Antoinette, ed. Domestic Service and the Formation of European Identity. Understanding the Globalization of Domestic Work, 16th-21st Centuries. Bern: Peter Lang, 2004.

Fauve-Chamoux, Antoinette, Sölvi Sogner, eds. Socio-Economic Consequences of SexRatios in Historical Perspective, 1500-1900. Milano: Università Bocconi, 1994.

Fialová, Ludmila. "Domestic Staff in the Czech Lands as the Turn of the 19th and 20th Centuries in the Light of Statistical Figures." In: Domestic Service and the Formation of European Identity. Understanding the Globalization of Domestic Work, 16th21st Centuries, ed. Antoinette Fauve-Chamoux, 141-159. Bern: Peter Lang, 2004.

Frątczak, Ewa. Modelowanie cyklu życia jednostki i rodziny. Teoria i praktyka. Warszawa: Oficyna Wydawnicza SGH, 1999.

Gapiński, Bartłomiej. Ludzie starzy na wsi polskiej od schyłku XIX wieku po rok 1939. Poznań: Wydawnictwo Nauka i Innowacje, 2014.

Gieysztorowa, Irena. Wstęp do demografii staropolskiej. Warszawa: Państwowe Wydawnictwo Naukowe, 1976.

Hajnal, John. "European Marriage Patterns in Perspective." In: Population in History. Essays in Historical Demography, eds. David V. Glass, David E.C. Eversley, 101143. London: Edward Arnold, 1965.

Hareven, Tamara K., ed. Transitions. The Family and the Life Course in Historical Perspective. New York-San Sebastian-London: Academic Press, 1978.

Henry, Louis, Yves Blayo. “La population de la France de 1740 à 1860.” Population 30 (1975), 1: 71-122.

Holzer, Jerzy Z. Demografia. Warszawa: Polskie Wydawnictwo Ekonomiczne, 1999.

Jaszczołt, Tomasz. "Fundacje kościelne na Podlasiu do końca XV wieku.” In: Kościoły a państwo na pograniczu polsko-litewsko-białoruskim. Źródła i stan badań, eds. 
Marek Kietliński, Krzysztof Sychowicz, Wojciech Śleszyński, 13-48. Białystok: Wydawnictwo Prymat Mariusz Śliwowski, 2005.

Kaczyńska, Elżbieta, Kazimierz Piesowicz. Wykłady z powszechnej historii gospodarczej (od schyłku średniowiecza do I wojny światowej). Warszawa: Państwowe Wydawnictwo Naukowe, 1977.

Kaźmierczyk, Ewa. "Spisy Komisji Porządkowej Cywilno-Wojskowej Województwa Krakowskiego jako źródło do badań demograficznych - przykład powiatu proszowickiego.” Przeszłość Demograficzna Polski 38 (2016), 2: 73-101.

Kędelski, Mieczysław, Jan Paradysz. Demografia. Poznań: Wydawnictwo Akademii Ekonomicznej w Poznaniu, 2006.

Kieniewicz, Stefan. Historia Polski 1795-1918. Warszawa: Państwowe Wydawnictwo Naukowe, 1970.

Kochanowicz, Jacek. Spór o teorię, Spór o teorię gospodarki chłopskiej. Gospodarstwo chłopskie w teorii ekonomii $i$ w historii gospodarczej. Warszawa: Wydawnictwa Uniwersytetu Warszawskiego, 1992.

Kopczyński, Michał. "Cykl życia jednostki na wsi polskiej u schyłku XVIII wieku.” Studia Demograficzne 127 (1997): 97-115.

Kopczyński, Michał. "Life Cycle in the Polish Countryside in the Late 18th Century." Acta Poloniae Historica 97 (2008): 75-94.

Kopczyński, Michał. "Life Cycle of Individuals in the Country of Poland at the End of the 18th Century." Polish Population Review 10 (1997): 228-247.

Kopczyński, Michał. Studia nad rodzina chłopska w Koronie w XVII-XVIII wieku. Warszawa: Wydawnictwo Krupski i S-ka, 1998.

Kotkowicz, Eryk. "Wieś i dwór podlaski z przełomu XIX i XX wieku w świetle wspomnień i pamiętników." In: Wolni $i$ uwłaszczeni. Chłopi a przemiany społeczno-gospodarcze $i$ polityczne $w$ Europie Wschodniej $w$ XIX $i$ na poczatku XX wieku, ed. Dorota Michaluk, 87-110. Ciechanowiec: Muzeum Rolnictwa im. ks. K. Kluka w Ciechanowcu - Urząd Marszałkowski Województwa Podlaskiego, 2017.

Krisań, Maria. Chłopi wobec zmian cywilizacyjnych w Królestwie Polskim w drugiej połowie XIX-początku XX wieku. Warszawa: Wydawnictwo Neriton, 2008.

Krisań, Maria. "Świadomość narodowa polskich chłopów w XIX w. widziana przez historiografię polską po drugiej wojnie światowej." Historyka 34 (2004): 123-141.

Kucharska, Jadwiga. "Stosunek do ziemi jako podstawy bytu mieszkańców wsi kujawskiej (wstępne wyniki badań z 1970 r.).” In: Zmiany kultury chłopskiej. Problematyka i metody prac etnograficznych, ed. Kazimiera Zawistowicz-Adamska, 219-227. Wrocław: Zakład Narodowy im. Ossolińskich, 1973.

Kuklo, Cezary. “Ludność parafii Trzcianne w świetle spisu wiernych z 1843 roku.” Przeszłość Demograficzna Polski 38 (2016), 3: 79-106.

Kuklo, Cezary. "Społeczno-demograficzny cykl życia człowieka w mieście staropolskim u schyłku XVIII wieku.” Roczniki Dziejów Społecznych i Gospodarczych 62 (2002): 85-105. 
Kussmaul, Ann. Servants in Husbandry in Early-Modern England. Cambridge: Cambridge University Press, 1981.

Laslett, Peter. "Characteristics of the Western Family Considered Over Time.” In: P. Laslett, Family Life and Illicit Love in Earlier Generations. Essays in Historical Sociology, 12-49. Cambridge: Cambridge University Press, 1977.

Laslett, Peter. "Family and Household as Work Group and Kin Group: Areas of Traditional Europe Compared.” In: Family Forms in Historic Europe, eds. Richard Wall, Joan Robin, 513-563. Cambridge: Cambridge University Press, 1983.

Livi Bacci, Massimo. La population dans l'histoire de l'Europe. Paris: Éditions du SEUIL, 1999.

Lundh, Christer, Satomi Kurosu et al., eds. Similarity in Difference. Marriage in Europe and Asia, 1700-1900. Cambridge: The MIT Press, 2014.

McIsaac Cooper, Sheila. "From Family Member to Employee: Aspects of Continuity and Discontinuity in English Domestic Service, 1600-2000." In: Domestic Service and the Formation of European Identity. Understanding the Globalization of Domestic Work, 16th-21 ${ }^{\text {st }}$ Centuries, ed. Antoinette Fauve-Chamoux, 277-296. Bern: Peter Lang, 2004.

Markowska, Danuta. Rodzina wiejska na Podlasiu 1864-1964. Wrocław: Zakład narodowy Imienia Ossolińskich, 1970.

Markowska, Danuta. Rodzina w społeczności wiejskiej-ciagłość i zmiana. Warszawa: Ludowa Spółdzielnia Wydawnicza, 1976.

Markowska, Danuta. “Z problematyki zmian struktury rodziny (rodzina wielopokoleniowa a ludzie starzy).” In: Zmiany kultury chłopskiej. Problematyka i metody prac etnograficznych, ed. Kazimiera Zawistowicz-Adamska, 151-175. Wrocław: Zakład Narodowy im. Ossolińskich, 1973.

Mędrzecki, Włodzimierz, Szymon Rudnicki, Janusz Żarnowski. Społeczeństwo polskie w XX wieku. Warszawa: Instytut Historii PAN, 2003.

Mironov, Boris N. "Long-term Trends in the Development in Christian Russia from the Sixteenth to the Twentieth Centuries: An Analytical Overview of Historiography." Journal of Family History 41 (2016), 4: 355-377.

Mironov, Boris N. Rossijskaja imperija: ot tradicii k moderny. Vol. 1. Sankt Peterburg: Sankt-Peterburgskij Gosudarstwiennyj Uniwersitet, 2014

Mitterauer, Michael. "Servants and Youth.” Continuity and Change 5 (1990), 5: 11-38.

Muzykant, S. "Włościańskie prawo spadkowe w województwie poleskim i 5 wschodnich powiatach wojew. białostockiego.” In: Adam Bobkowski, S. Muzykant, Kazimierz Petrusiewicz, Witold Sienkiewicz, Zwyczaje spadkowe włościan w Polsce. Cz. IV: Zwyczaje spadkowe wtościan w czterech województwach kresowych, 177-304. Warszawa: Nakładem Państw. Instytutu Naukowego Gosp. Wiejsk. w Puławach, 1929.

Perrenoud, Alfred. 'Le recul de la mortalité 'ordinaire'.” In: Histoire des populations de l'Europe. Vol. 1: La revolution démographique 1750-1914, eds. Jean-Pierre Bardet, Jacques Dupâquier, 57-83. Paris: Fayard, 1998. 
Plakans, Andrejs. "Agrarian Reform and the Family in Eastern Europe." In: Family Life in the Long Nineteenth Century 1789-1913, eds. David I. Kertzer, Marco Barbagli, 73-105. New Haven-London: Yale University Press, 2002.

Polla, Matti. "Family Systems in Central Russia in the 1830s and 1890s." The History of the Family 11 (2006), 1: 27-44.

Poniat, Radosław. Służba domowa w miastach na ziemiach polskich od połowy XVIII do końca XIX wieku. Warszawa: Wydawnictwo DiG, 2014.

Poniat, Radosław. "Starość ludzi luźnych. Aspekty demograficzne i ekonomiczne." In: Ludzie starzy i starość na ziemiach polskich od XVIII do XXI wieku (na tle porównawczym). Vol. 1: Metodologia, demografia, instytucje opieki, eds. Agnieszka Janiak-Jasińska, Katarzyna Sierakowska, Andrzej Szwarc, 133-147. Warszawa: Wydawnictwo DiG, 2016.

Schlumbohm, Jürgen. "From Peasant Society to Class Society: Some Aspects of Family and Class in a Northwest German Protoindustrial Parish, 17th-19th Centuries." Journal of Family History 17 (1992), 2: 183-199.

Smith, Richard M., ed. Land, Kinship and Life-Cycle. Cambridge: Cambridge University Press, 1984.

Spoorenberg, Thomas. "La qualité des declarations par âge extension et application de l'indice de Whipple modifié." Population 62 (2007), 4: 847-859.

Stomma, Ludwik. Antropologia kultury wsi polskiej XIX wieku oraz wybrane eseje. Łódź: Wydawnictwo Piotr Dopierało, 2002.

Szołtysek, Mikołaj. "Demografia historyczna i co dalej? Nowe perspektywy w badanaich nad historią rodziny XVI-XIX wieku." Roczniki Dziejów Społecznych i Gospodarczych 62 (2003): 132-137.

Szołtysek, Mikołaj. Rethinking East-Central Europe: Family Systems and Co-Residence in the Polish-Lithuanian Commonwealth. Vols. 1-2. Bern: Peter Lang, 2015.

Szumski, Jerzy. "Uwłaszczenie chłopów w obwodzie białostockim oraz w północno-wschodniej części Królestwa Polskiego.” In: Wieś i rolnictwo ziem pótnocno-wschodniej Polski w II polowie XIX i poczatkach XX w., ed. Adam Dobroński, 9-134. Białystok: Dział Wydawnictw Filii Uniwersytetu Warszawskiego w Białymstoku, 1984.

Thomas, William I., Florian Znaniecki. The Polish Peasant in Europe and America. Vol. 1. New York: Alfred A. Knopf, 1927.

Van Poppel, Frans, Michel Oris. "Introduction.” In: The Road to Independence. Leaving Home in Western and Eastern Societies, 16th-20th Centuries, eds. Frans van Poppel, Michel Oris, James Lee, 1-29. Bern: Peter Lang, 2004.

Wall, Richard. "Leaving Home and the Process of Household Formation in Pre-Industrial England." Continuity and Change 2 (1987), 1: 77-101.

Wiślicz, Tomasz. Upodobanie. Matzeństwo i zwiąki nieformalne na wsi polskiej XVIIXVIII wieku. Wrocław: Wydawnictwo Chronicon, 2012.

Woźniak, Andrzej. Kultura mazowieckiej wsi pańszczyźnianej XVIII i poczatku XIX wie$k u$. Wrocław: Zakład Narodowy im. Ossolińskich, 1987. 


\section{Did the Abolition of Serfdom Affect the Life Cycle of Peasants in the Western Part of the Grodno Governorate in the 19th and Early 20th Centuries?}

\section{Summary}

The objective of the article is an attempt to answer the question if the agrarian reforms of the 1860s carried out in Russia affected the individual's life cycle in Catholic families of peasants in Podlasie, which, after 1807, was included in the Grodno Governorate. In Polish historiography the subject of the individual and the family's life cycle in the 19 th century has not yet been adequately researched. Hence these studies are supposed to fill this gap, at least in part. In this paper, a cross-section analysis of demographic phenomena was employed, which is based on three lists of the inhabitants of the large Podlasie parish of Trzcianne, compiled in the years 1843-1910. In 1843, the cohort of Trzcianne peasants included over 2,000 people, in 1882 nearly 4,300, and in 1910 over 6,000 people. The research value of the lists was evaluated with the help of three indexes: Whipple's index, modified Whipple's index $\left(\mathrm{W}_{t o t}\right)$ and $\mathrm{ABCC}$. The register of the faithful compiled in 1910, in comparison with two earlier statistical representations of the population of Trzcianne parish, stood out clearly with its meticulousness in terms of the residents' ages recorded in it.

The application of the cross-section method aimed at illustrating the dependence between the age and the status of the individual (children, household servants, householders, independent female heads of households, relatives and lodgers) in the household. The article devotes more attention to the pace of children's leaving family homes, as well as the status of old people, i.e., 65 years old and older, always including their sex.

The results of the study show that towards the end of serfdom, childhood ended relatively soon, usually after 10 years of age, since the group of older boys were hired as paid workers. For the subsequent 10 years an increasing group of them joined the ranks of servants, because being a servant was not a discrediting occupation and for most of them it was just a transitional stage of life. A more serious change in Podlasie serfs' lives occurred at around 30 years of age. The group of unmarried men diminished, just like the group of servants, and half of the men managed their own household which they passed on to the younger generation after they turned 55. Men lived as relatives in their family's household more seldom than women; they were mostly young and able to work hard, which enriched the household workforce.

Women's life cycle had the same stages as their brothers', even though it was moved in time. Furthermore, peasants' daughters, when older, found paid work as servants and left their parents' households sooner than their brothers, which was also related to their earlier marriage. However, after 40, they experienced widowhood more often than men, which was usually tantamount to becoming an independent head of household. In the village under serfdom, they managed every seventh household. Most of them lived modest lives. Over a half of them were housed as relatives with the families of their married children, and almost one in five lived until death renting at strangers' houses. 
Nearly half a century after emancipation, on the threshold of the 20th century, peasants' sons remained in their parents' households much longer, with certain exceptions until the age of 25. The changed economic and legal circumstances of the functioning of the peasant household after the agrarian reforms forced them to abandon the family home, which was tantamount to the elimination of the customary second stage in their lives, which was temporary work as labourers. Assuming the position of manager of the household took place slightly later than in the period of serfdom, but they also remained longer in this position, practically until the age of 65 . Throughout their lives, most of the Podlasie peasants experienced the independent managing of their own household, for they hardly ever lived as relatives in the families of their married children.

Peasants' daughters, like their brothers, did not experience temporary work as female servants and until the age of 20 they remained in their parents' household. They started their own family as a result of marriage within the following 10 years of life. Only after 50 , i.e., ten years later in comparison with the period of serfdom, did they more often become heads of households, as a result of their husbands' death. They were independent heads of every eighth peasant household. Towards the end of their lives, having turned 65 , their social situation was far worse than that of men at the same age, but slightly better than that of their grandmothers during the last decades of serfdom. Half of them still lived their final years with their married children, but over $42 \%$ were either householders' wives or independent heads of households.

In the light of the materials used, it seems justified to detect an atomization of Podlasie peasant families at the turn of the 20th century, and the fact that the fundamental elements of the family system of the Podlasie peasants living in the Grodno Governorate were more similar to Western Europe than Russia.

\section{Czy uwłaszczenie wpłynęło na cykl życiowy chłopów w zachodniej części guberni grodzieńskiej w XIX i początkach XX wieku?}

\section{Streszczenie}

Celem artykułu jest próba odpowiedzi na pytanie, czy reformy agrarne lat 60 . XIX wieku przeprowadzone w Rosji wpłynęły na cykl życia jednostki w rodzinach katolickich chłopów na Podlasiu, które po 1807 roku zostało włączone w skład guberni grodzieńskiej. W polskiej historiografii temat cyklu życia jednostki i rodziny w XIX wieku jest nieopracowany, zatem niniejsze badania mają wspomnianą lukę choć w części wypełnić. W pracy posłużono się metodą przekrojową, opartą na trzech spisach mieszkańców dużej parafii podlaskiej Trzcianne, sporządzonych w latach 1843-1910. Kohorta chłopów trzciańskich w 1843 roku liczyła ponad 2 tys. osób, w 1882 r. - blisko 4,3 tys. osób, zaś w 1910 r. - ponad 6 tys. osób. Wartość badawczą spisów oceniono, stosując trzy indeksy: Whipple'a, zmodyfikowany Whiplle'a $\left(\mathrm{W}_{\text {tot }}\right)$ oraz ABCC. Zrealizowany w 1910 roku 
spis wiernych, na tle dwóch wcześniejszych ujęć statystycznych ludności badanej parafii, wyróżniał się zdecydowanie dokładnością w zakresie odnotowanego w nim wieku mieszkańców.

Zastosowanie przekrojowej analizy zjawisk demograficznych miało na celu zobrazowanie zależności między wiekiem a pozycją jednostki (dzieci, służba domowa, gospodarze, samodzielne kierowniczki gospodarstw, krewni i kątnicy) w gospodarstwie domowym. W artykule w większym stopniu zwrócono uwagę na tempo opuszczania przez dzieci chłopskie domu rodzinnego oraz na pozycję ludzi starych, to jest w wieku 65 i więcej lat, zawsze $\mathrm{z}$ uwzględnieniem ich płci.

Wyniki badania wskazują, że u schyłku doby pańszczyźnianej dzieciństwo kończyło się stosunkowo szybko, zazwyczaj po 10. roku życia, gdyż już część starszych chłopców wynajmowała się do płatnej pracy najemnej. Przez następne 10 lat życia coraz większa ich grupa zasilała szeregi czeladzi, ale dla większości praca w charakterze parobka była jedynie przejściowym etapem w życiu. Poważniejsza zmiana w życiu podlaskich chłopów pańszczyźnianych dokonywała się około 30. roku życia. Maleje grupa synów bezżennych, podobnie jak i grupa służących, a połowa mężczyzn kieruje gospodarstwem domowym, które przekazują w ręce młodszego pokolenia po przekroczeniu 55 lat życia. Mężczyźni rzadziej niż kobiety występowali w roli krewnych, w większości byli młodzi i zdolni do pracy fizycznej, dzięki czemu wzbogacali zasób siły roboczej gospodarstwa.

Cykl życiowy kobiety w okresie dzieciństwa i młodości był podobny do ich braci, choć nieco przesunięty w czasie. Także córki chłopskie w starszym wieku najmowały się do płatnej służby i szybciej niż bracia opuszczały gospodarstwo rodziców, nie bez związku z wczesnym zamążpójściem. Jednakże po ukończeniu 40 lat częściej niż mężczyźni doświadczały wdowieństwa, które było równoznaczne zazwyczaj z objęciem funkcji samodzielnej kierowniczki gospodarstwa. Na wsi pańszczyźnianej kierowały co siódmym gospodarstwem domowym. W dotychczasowym cyklu ich życia w porównaniu z mężczyznami wiele zmieniała starość. Większość z nich wiodła skromny żywot. Ponad połowa zamieszkiwała kątem jako krewne w rodzinach pożenionych dzieci i prawie co piąta dożywała, podnajmując kąt u obcych ludzi.

Blisko pół wieku po uwłaszczeniu, na progu XX wieku, synowie chłopscy pozostawali w gospodarstwie rodziców znacznie dłużej, z pewnymi wyjątkami, aż do 25 . roku życia. Zmienione warunki ekonomiczne i prawne funkcjonowania gospodarstwa chłopskiego po reformach agrarnych wymusiły porzucenie przez nich wczesnego opuszczania domu rodzinnego, co było równoznaczne z likwidacją zwyczajowego drugiego etapu w ich życiu, to jest okresowego najmowania się do pracy w charakterze parobków. Przejęcie funkcji kierownika gospodarstwa domowego następowało trochę później niż w dobie pańszczyźnianej, ale też dłużej pozostawali oni na funkcji, praktycznie aż do 65. roku życia. Większość chłopów podlaskich w całym swoim dorosłym życiu doświadczała samodzielnego kierowania własnym gospodarstwem, gdyż bardzo rzadko występowali oni w charakterze krewnych w rodzinach pożenionych dzieci. 
Córki chłopskie, podobnie jak ich bracia, nie znały okresowej pracy w charakterze dziewek służebnych i aż do ukończenia 20 lat pozostawały w gospodarstwie rodziców. Opuszczenie przez nie dotychczasowego gniazda rodzinnego w wyniku zamążpójścia następowało w następnych 10 latach życia. Dopiero po ukończeniu 50 lat, a więc dziesięć lat później w porównaniu z epoką pańszczyźnianą, częściej stawały na czele gospodarstw na skutek śmierci męża. Kierowały samodzielnie co ósmym gospodarstwem chłopskim. U schyłku swojego życia po przekroczeniu 65 lat ich położenie społeczne było dużo gorsze niż mężczyzn w tym samym wieku, ale trochę lepsze niż ich babek w ostatnich dekadach funkcjonowania pańszczyzny. Wprawdzie nadal ponad połowa $\mathrm{z}$ nich przeżywała swoje ostatnie lata u boku pożenionych dzieci, ale ponad $42 \%$ było albo żonami gospodarzy, albo samodzielnymi kierowniczkami gospodarstw.

W świetle spożytkowanych materiałów wydaje się być uprawnione stwierdzenie o zarysowującej się atomizacji rodziny chłopów podlaskich w końcu XIX i początkach $\mathrm{XX}$ wieku oraz że podstawowe elementy systemu rodzinnego chłopów podlaskich zamieszkałych w guberni grodzieńskiej były bardziej podobne do Europy Zachodniej niż do Rosji. 